\title{
Cumulate xenoliths from St. Vincent, Lesser Antilles Island Arc: a window into upper crustal differentiation of mantle-derived basalts
}

\author{
P. M. E. Tollan · I. Bindeman · J. D. Blundy
}

Received: 13 December 2010/Accepted: 14 June 2011/Published online: 29 June 2011

(C) Springer-Verlag 2011

\begin{abstract}
In order to shed light on upper crustal differentiation of mantle-derived basaltic magmas in a subduction zone setting, we have determined the mineral chemistry and oxygen and hydrogen isotope composition of individual cumulus minerals in plutonic blocks from St. Vincent, Lesser Antilles. Plutonic rock types display great variation in mineralogy, from olivine-gabbros to troctolites and hornblendites, with a corresponding variety of cumulate textures. Mineral compositions differ from those in erupted basaltic lavas from St. Vincent and in published high-pressure (4-10 kb) experimental run products of a St. Vincent high$\mathrm{Mg}$ basalt in having higher $A n$ plagioclase coexisting with lower $F o$ olivine. The oxygen isotope compositions $\left(\delta^{18} \mathrm{O}\right)$ of cumulus olivine (4.89-5.18\%), plagioclase (5.84-6.28\%), clinopyroxene $(5.17-5.47 \%$ ) and hornblende $(5.48-5.61 \%$ ) and hydrogen isotope composition of hornblende $(\delta \mathrm{D}=$ -35.5 to $-49.9 \%$ ) are all consistent with closed system magmatic differentiation of a mantle-derived basaltic melt. We employed a number of modelling exercises to constrain
\end{abstract}

Communicated by J. Hoefs.

Electronic supplementary material The online version of this article (doi:10.1007/s00410-011-0665-9) contains supplementary material, which is available to authorized users.

P. M. E. Tollan · J. D. Blundy

Department of Earth Sciences, University of Bristol,

Wills Memorial Building, Bristol BS8 1RJ, UK

I. Bindeman

Department of Geological Sciences, University of Oregon,

Eugene, OR 97403-1272, USA

P. M. E. Tollan $(\bowtie)$

Department of Earth Sciences, Durham University,

Science Labs, Durham DH1 3LE, UK

e-mail: p.m.e.tollan@durham.ac.uk the origin of the chemical and isotopic compositions reported. $\delta^{18} \mathrm{O}_{\text {Olivine }}$ is up to $0.2 \%$ higher than modelled values for closed system fractional crystallisation of a primary melt. We attribute this to isotopic disequilibria between cumulus minerals crystallising at different temperatures, with equilibration retarded by slow oxygen diffusion in olivine during prolonged crustal storage. We used melt inclusion and plagioclase compositions to determine parental magmatic water contents (water saturated, $4.6 \pm 0.5 \mathrm{wt} \% \mathrm{H}_{2} \mathrm{O}$ ) and crystallisation pressures $(173 \pm 50 \mathrm{MPa})$. Applying these values to previously reported basaltic and basaltic andesite lava compositions, we can reproduce the cumulus plagioclase and olivine compositions and their associated trend. We conclude that differentiation of primitive hydrous basalts on St. Vincent involves crystallisation of olivine and $\mathrm{Cr}$-rich spinel at depth within the crust, lowering $\mathrm{MgO}$ and $\mathrm{Cr}_{2} \mathrm{O}_{3}$ and raising $\mathrm{Al}_{2} \mathrm{O}_{3}$ and $\mathrm{CaO}$ of residual melt due to suppression of plagioclase. Low density, hydrous basaltic and basaltic andesite melts then ascend rapidly through the crust, stalling at shallow depth upon water saturation where crystallisation of the chemically distinct cumulus phases observed in this study can occur. Deposited crystals armour the shallow magma chamber where oxygen isotope equilibration between minerals is slowly approached, before remobilisation and entrainment by later injections of magma.

Keywords St. Vincent - Lesser - Antilles - Oxygen · Hydrogen · Isotopes · Cumulates · Differentiation . Fractional $\cdot$ Crystallisation $\cdot$ Disequilibrium

\section{Introduction}

The generation and evolution of arc magmas are strongly influenced by the interaction of hydrous, slab-derived 
material(s) and mantle wedge peridotite and subsequent differentiation of mantle-derived hydrous magmas in intracrustal magma chambers (Arculus 1994; Elliott et al. 1997; Grove et al. 2009 and references within). Establishing the relative roles of these materials and processes in producing compositions parental to erupted and non-erupted magmatic products provides an important insight into the recycling of crustal material over geological history.

The vast majority of work investigating volcanic arc magmatic processes involves the study of extrusive rocks. Whilst this provides a plethora of useful information, the resolution with which any particular individual process can be investigated is greatly reduced since extrusive rocks represent an end product of all contributing pre-eruptive petrogenetic processes. Few erupted arc magmas are sufficiently primitive to be in equilibrium with mantle wedge peridotite, meaning a significant volume of arc crust must comprise plutonic cumulates formed during differentiation of primitive basalts to more evolved arc magmas. This cumulate material is typically not readily available for petrological study, except in case of deeply eroded ancient arcs (e.g. DeBari and Coleman 1989; Greene et al. 2006). A notable exception amongst active arcs is the Lesser Antilles, which is renowned for the remarkable abundance and variety of its cumulate xenoliths (Lewis 1973; Arculus and Wills 1980). Additionally, several Lesser Antilles islands erupt primitive basaltic magmas that are close to being in equilibrium with the mantle wedge (Macdonald et al. 2000).

In this study, we utilise a texturally and compositionally diverse collection of plutonic cumulate xenoliths from the island of St. Vincent to provide detailed insights into magmatic evolution in the crust. St. Vincent is particularly well suited to this type of study as it has also erupted primitive basalts, with compositions close to equilibrium with the mantle wedge (Heath et al., 1998). We report the major element and stable (oxygen and hydrogen) isotope compositions of cumulus minerals, which we use to explore the roles of crustal contamination, fractional crystallisation and intra-crustal residence in generating cumulate petrology and geochemistry. We compare our results to the previous experimental studies of basalt differentiation at St. Vincent and hypothesise on the nature of crustal differentiation at St. Vincent and its relationship to the erupted volcanics.

\section{Study area}

The Lesser Antilles (Fig. 1) is an active oceanic island arc formed as a result of the slow ( $\sim 2 \mathrm{~cm} /$ year), westwards subduction of the Atlantic plate underneath the Caribbean plate (see Macdonald et al. 2000 for a detailed overview).

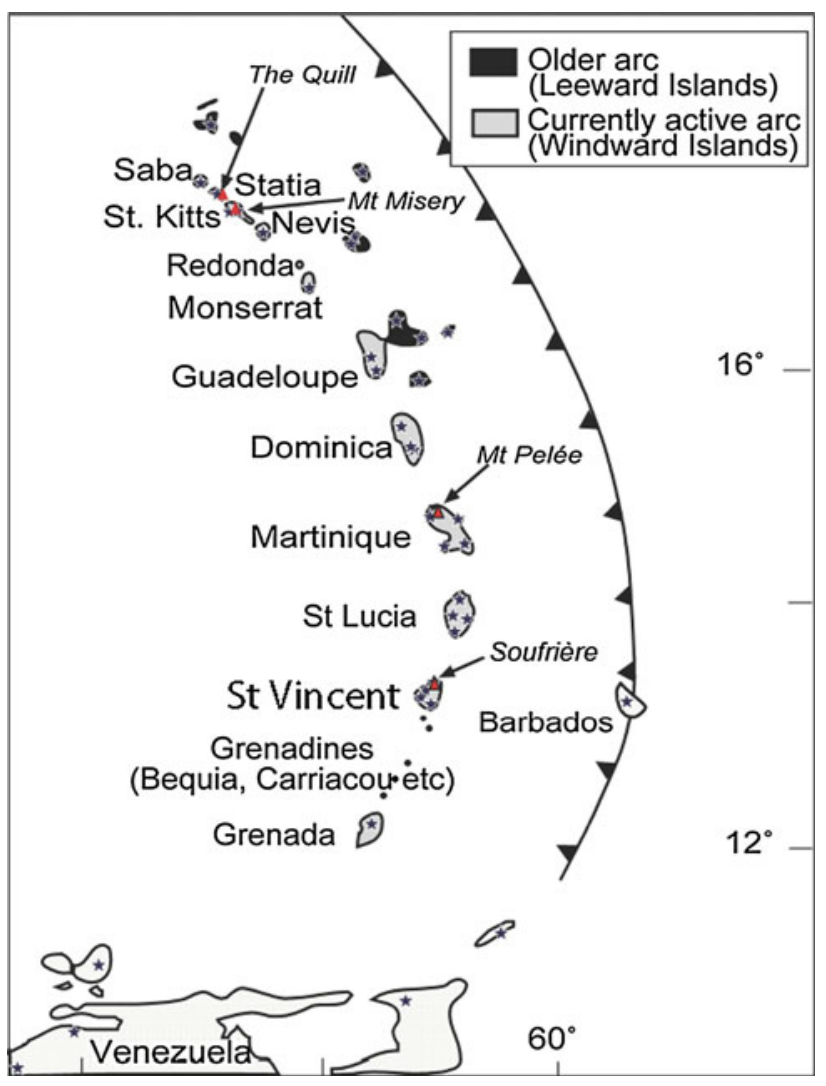

Fig. 1 Map of the Lesser Antilles Island Arc showing the location of the active volcanic arc and the island of St. Vincent and the approximate location of the trench

The arc is approximately $750 \mathrm{~km}$ long, with volcanic islands positioned along its length spaced at $15-125 \mathrm{~km}$ intervals. There is considerable geochemical variation along the length of the arc. Islands to the north (Saba to Monsterrat) produce low- $\mathrm{K}$ basalts whereas those in the south (Grenadines and Grenada) comprise medium- $\mathrm{K}$ picrites and ankaramites. The central islands (Guadeloupe to Bequia) are typically composed of medium-K basalt or basaltic-andesite, but many central islands produce both low- and medium- $\mathrm{K}$ varietes. The overall increase in $\mathrm{K}_{2} \mathrm{O}$ and decrease in silica saturation further south is accompanied by greater enrichment in light rare earth elements (LREE) and greater diversity in both trace element and isotopic compositions (Macdonald et al. 2000).

St. Vincent is located towards the south of the central group of islands and is a good example of a transitional island, having erupted both low- and medium-K basalts and basaltic-andesites (Heath et al. 1998). Of particular interest are the eruptions of high magnesia basalts (HMB, $\mathrm{Mg} \#>70, \mathrm{MgO}>10 \mathrm{wt} \%$ ), which are thought to represent near-primary mantle melts. Through study of the HMB, Heath et al. (1998) concluded that primary melts beneath St. Vincent were generated at $\sim 17 \mathrm{kbar}$, $>1,130^{\circ} \mathrm{C}$ and $f \mathrm{O}_{2}>\mathrm{FMQ}+1$. Experiments by Pichavant 
et al. (2002) on a St. Vincent HMB $(\mathrm{Mg \#}=89)$ revealed melt extraction conditions from mantle peridotite to be $1,235^{\circ} \mathrm{C}$ and $11.5 \mathrm{kbar}$ with $1.5 \mathrm{wt} \% \mathrm{H}_{2} \mathrm{O}$ or $1,185^{\circ} \mathrm{C}$ and 16 kbar with 4.5 wt $\% \mathrm{H}_{2} \mathrm{O}$. Primary $\mathrm{H}_{2} \mathrm{O}$ contents of 0.9-3.5 wt\% are supported by analysis of olivine-hosted melt inclusions (Bouvier et al. 2008). McDade et al. (2003) used trace element systematics of a St. Vincent HMB to estimate that it was formed by $\sim 18 \%$ partial melting of a mantle source that was contaminated by slab-derived fluids. The mantle source to which the slab fluid was added had itself been previously depleted, relative to primitive upper mantle, by prior extraction of some $4.4 \%$ of partial melt. Trace element contents in the HMB lavas are typical of arc magmas and generally consistent with closed system fractional crystallisation of a mantle-derived parent being the dominant magmatic process (Heath et al. 1998). An exception is the observed depletion of LREE with magmatic evolution, which could reflect multiple magmatic lineages, originating from basaltic parents with variable LREE. This finding was supported by analyses of olivinehosted melt inclusions by Bouvier et al. (2008, 2010), who concluded that heterogeneities in parental magmas combined with shallow-level differentiation processes were the only way to explain fully geochemical variation.

Oxygen isotope compositions (as $\delta^{18} \mathrm{O}$ values) of Lesser Antilles lavas vary greatly, even for those erupted from a single island, which is thought to be due primarily to variable assimilation of crust during fractional crystallisation. Van Soest et al. (2002) concluded, based on a combined $\mathrm{He}-\mathrm{O}-\mathrm{Sr}$ isotope study, that lavas in the northern arc were predominantly uncontaminated, whereas islands further south (including St. Vincent) recorded more pervasive contamination leading to $\delta^{18} \mathrm{O}$ values both higher and lower than the mantle value. Davidson and Harmon (1989) and Thirlwall et al. (1996) found elevated $\delta^{18} \mathrm{O}$ values for Martinique and Grenada, respectively. Smith et al. (1996) identified two isotopically distinct lava suites on Bequia, one with mantle-like $\delta^{18} \mathrm{O}$ values and another with highly elevated values $\left(\delta^{18} \mathrm{O}_{\text {Clinopyroxene }} \leq 7.6 \%\right)$. Similarly, whilst Van Soest et al. (2002) found normal $\delta^{18} \mathrm{O}$ values for Montserrat, Zellmer et al. (2003) found elevated values, again indicating the highly variable influence of crustal material on magmatic evolution over a very restricted spatial area. All oxygen isotope studies so far have been limited, in that they generally only investigate erupted lavas, which represent the time-integration of a variety of processes, such as source contamination, magma mixing, fractional crystallisation and crustal assimilation. This restricts the information that can be learnt about how these different processes influence magmatic evolution over the entire crustal profile. Analysis of cumulus minerals provides an important complement to whole-rock volcanic samples.

\section{Methods}

Electron microprobe analyses were performed at the University of Bristol on a Cameca SX-100 instrument with a $20 \mathrm{kV}$ accelerating voltage and a $10 \mathrm{nA}$ beam current, calibrated on a variety of mineral and glass standards. A total of 325 spot analyses were made on plagioclase, olivine, clinopyroxene, hornblende, orthopyroxene and spinel, with both core and rim analysed for each crystal. $\mathrm{Fe}_{2} \mathrm{O}_{3}$ was determined by stoichiometry using the method of Droop (1987) for spinel and clinopyroxene and Holland and Blundy (1994) for hornblende.

Oxygen isotope analyses were performed using a Finnigan MAT 253 mass spectrometer with attached laser fluorination line at the stable isotope laboratory, University of Oregon. Approximately $1.5( \pm 0.5) \mathrm{mg}$ of each mineral sample was hand-picked and then loaded into the sample holder. The cumulates were generally coarse-grained and poorly cemented enough to allow removal of crystals by light crushing of each sample. Crystals were then studied in detail by optical microscope to select those with the least surface alteration and mineral/melt inclusions. Where possible, single crystals were analysed to minimise contamination and highlight single-phase heterogeneity, but in finer-grained samples up to 7 crystals were analysed in bulk. In most cases, individual minerals showed exceptional clarity with no signs of subsolidus alteration. Minerals were pre-treated in the sample holder overnight with an aliquot of $\mathrm{BrF}_{5}$, before being lased under a reactive atmosphere of $\mathrm{BrF}_{5}$ to extract the gas. A series of cryogenic traps held at liquid nitrogen temperature and a mercury diffusion pump were used to purify and isolate oxygen gas, which was then converted to $\mathrm{CO}_{2}$ using a small platinumgraphite filament before being fed into the mass spectrometer. Repeat analyses were made of mineral samples, which produced unusual yields or $\delta^{18} \mathrm{O}$ values. The standard used was Gore Mountain Garnet $\left(\delta^{18} \mathrm{O}=5.75 \%\right.$ ) because it has similar lasing properties to the relatively iron-rich olivines studied in this work. All analyses were corrected by applying the average deviation from this value over 4-5 standard measurements over the course of each day. The analyses were conducted over a period of 4 days. As running a sample in duplicate and triplicate during several analytical sessions represents the most robust way to estimate the $\delta^{18} \mathrm{O}$ value of the unknown relative to the laboratory standard, we estimate that external precision of this dataset based on standards and unknowns is better than $0.1 \%$. Standard deviation $(1 \sigma)$ of repeat analyses of plagioclase and olivine was 0.1 and $0.06 \%$, respectively.

Hydrogen isotope measurements used $3 \pm 0.5 \mathrm{mg}$ of individual and bulk crystals and were performed in continuous flow mode using helium UHP carrier gas and a TC/ EA furnace with glassy carbon (improved on the method in 
Sharp et al. 2001) that is integrated with the large radius MAT253 mass spectrometer at the University of Oregon. This allows sample size to be 2-4 times smaller than for more commonly available TC/EA-Delta set-ups. Three standards were used during the analytical session (NBS30 biotite, $\delta \mathrm{D}=-66 \%$, Butte Montana BUD biotite $\delta \mathrm{D}=$ $-161.8 \%$ and RUH2 muscovite, $\delta \mathrm{D}=-98.2 \%$ ), spanning a range of $95 \%$ and overlapping with the ranges of the unknowns. A three-point calibration was applied using offsets between obtained $\delta \mathrm{D}$ values and the quoted values for mica standards run during each analytical session. Instrumental mass fractionation offsets were typically between 20 and 30\%o, and the magnitude of offset differed by less than $10 \%$ in low versus high $\mathrm{D} / \mathrm{H}$ ends. Based on duplicate sample analyses, the 1 standard deviation ranged from 0.3 to $4.25 \%$ with an average of $1.89 \%$.

\section{Sample petrology and geochemistry}

Cumulate xenoliths are unusually common on St. Vincent (Lewis 1973). They occur throughout the island, typically ex situ in small stream beds where they become gravitationally concentrated. Most of the xenoliths in this study were collected close to the Soufriere volcano on paths near the crater or in river valleys as loose blocks, during a field expedition in 2009. Full petrographic descriptions of the samples studied are presented in Table 1.

\section{Mineralogy}

The dominant mineralogy of the cumulate xenoliths studied is plagioclase + olivine + clinopyroxene \pm hornblende \pm spinel. Orthopyroxene is notably absent with the exception of trace amounts in the groundmass of two samples (VS2A and VS46). Mineral modes were obtained by point counting, using a total of 1,500-3,000 points, depending on the homogeneity of the thin section (Table 1). The volume mode obtained in this way was converted to mass mode using accepted mineral densities, with solid solutions corrected for (Deer et al. 1996). The samples varied greatly in terms of the modal proportions of the main minerals (Fig. 2) and have been classified as gabbros, troctolites, hornblendites or pyroxenites (according to the classification scheme of Streckeisen 1976).

Olivine gabbros (Fig. 3a) were the most common xenolith type, with additionally variable and often significant amounts of hornblende in addition to the typical gabbroic assemblage of olivine + plagioclase + clinopyroxene. The groundmass, where present, is generally dominated by plagioclase but with varying amounts of all other main phases. Troctolites (Fig. 3b) are defined by the predominance of olivine over clinopyroxene. Of the three troctolites studied, two lacked hornblende. Hornblendites (Fig. 3c) are defined as having bimodal mineralogies with significant proportions of hornblende. Two of the hornblendites (VS3-2 and VS5) had high modal plagioclase along with hornblende, whereas layer 2 of the layered cumulate, VS18, had high modal olivine without plagioclase. Hornblendes often display a poikilitic texture, with large oikocrysts (up to $2 \mathrm{~cm}$ ) enclosing numerous subhedral crystals of olivine, plagioclase, clinopyroxene and spinel. One sample (VS20) was classified as an olivinehornblende pyroxenite, due to a very unusual mineralogy comprising of an almost complete absence of plagioclase, very little olivine and an abundance of clinopyroxene and hornblende.

\section{Texture}

Cumulate textures vary between samples. Adcumulates (Fig. 3d) were the most common, with heteradcumulates (Fig. 3e) being the dominant cumulate texture where intercumulus material was present. Only one orthocumulate (VS2A; Fig. 3a) was analysed in this study. Crystal size varied, but was generally between 1 and $3 \mathrm{~mm}$, with several samples displaying very coarse crystals $(5-20 \mathrm{~mm})$. Plagioclase, hornblende and clinopyroxene were typically larger than coexisting olivine with spinel a minor included or intercumulus phase. Nearly all cumulates are remarkably well equilibrated, often displaying perfect $120^{\circ}$ grain boundaries. Crystal margins show little or no alteration, zoning or resorption textures, demonstrating that individual cumulate blocks formed during a single episode of growth over a narrow range of intensive parameters and experienced no significant textural re-equilibration during transport or post-eruption. An exception to this is VS48, which contains the cumulate-host magma contact and displays a greater variety of plagioclase textures (Fig. 3f). Similarly, the hand specimen of VS53 showed two distinct plagioclase populations when picking, although these were not apparent from the thin sections, suggesting that this was unique to the surface of the sample.

Crystallisation sequence was determined through textural inspection. Olivine is usually the first phase to appear, whilst hornblende is the last. Spinel generally appears to coprecipitate with olivine and/or clinopyroxene, with the notable exception of the ultramafic sample VS18, which contains Cr-rich spinels crystallising first in the sequence. An important correlation is observed between the presence of hornblende in a sample and the relative appearance of plagioclase in the crystallisation sequence. Where hornblende is present, plagioclase tends to crystallise after clinopyroxene whereas in samples without hornblende, plagioclase crystallises before clinopyroxene. This rules out a simple, common magmatic lineage for all cumulates 


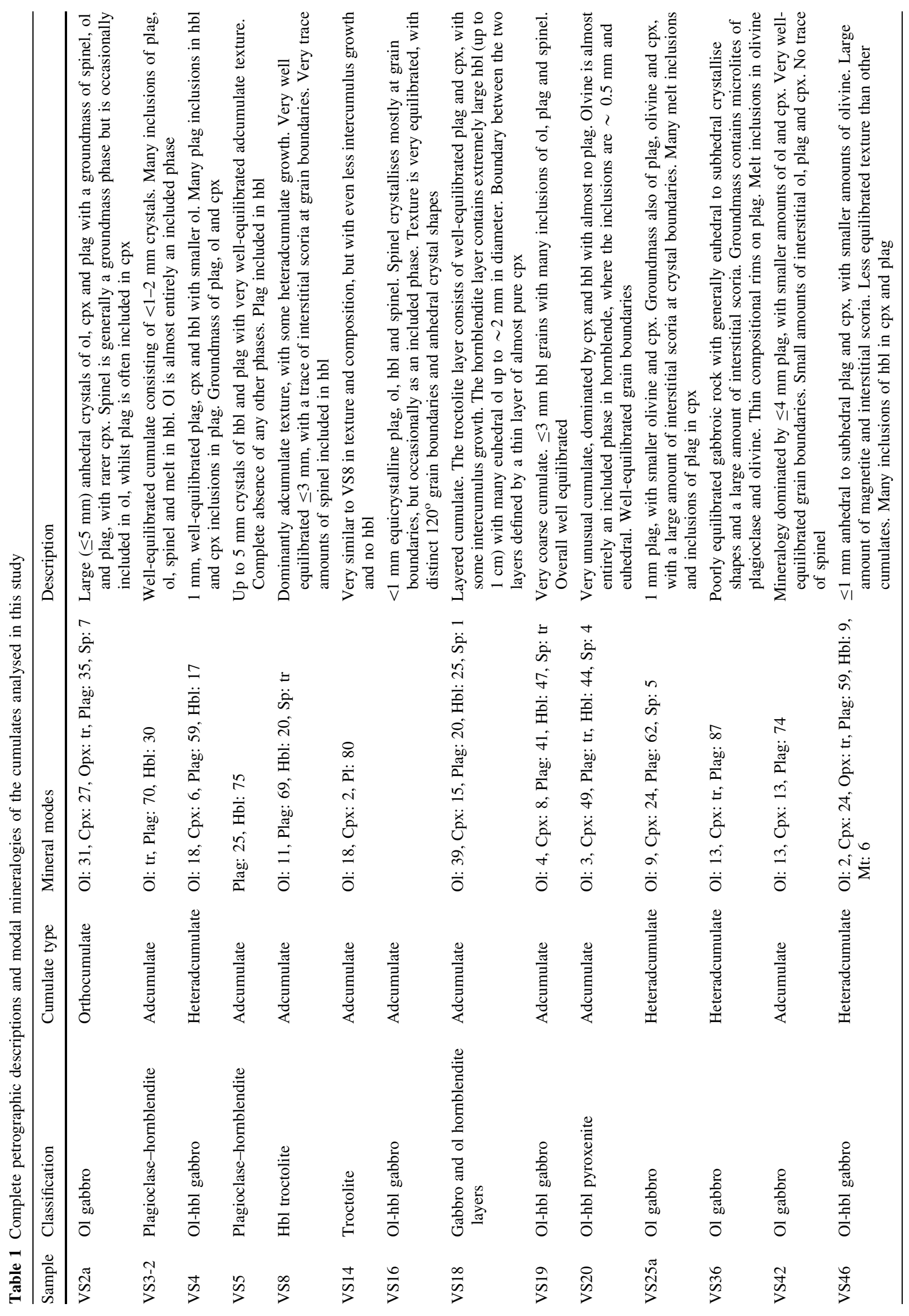



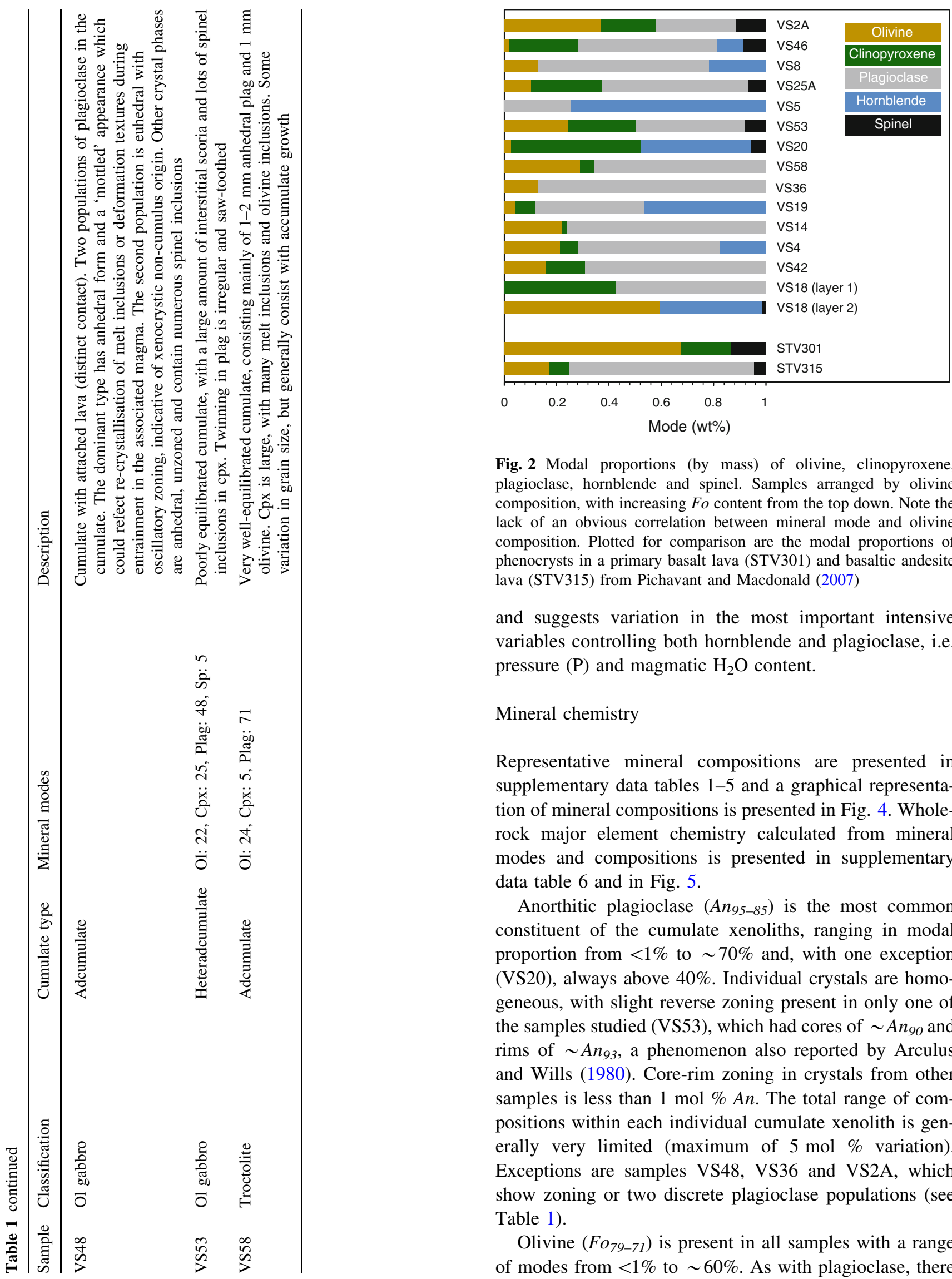

Fig. 2 Modal proportions (by mass) of olivine, clinopyroxene, plagioclase, hornblende and spinel. Samples arranged by olivine composition, with increasing $F o$ content from the top down. Note the lack of an obvious correlation between mineral mode and olivine composition. Plotted for comparison are the modal proportions of phenocrysts in a primary basalt lava (STV301) and basaltic andesite lava (STV315) from Pichavant and Macdonald (2007)

and suggests variation in the most important intensive variables controlling both hornblende and plagioclase, i.e. pressure $(\mathrm{P})$ and magmatic $\mathrm{H}_{2} \mathrm{O}$ content.

\section{Mineral chemistry}

Representative mineral compositions are presented in supplementary data tables $1-5$ and a graphical representation of mineral compositions is presented in Fig. 4. Wholerock major element chemistry calculated from mineral modes and compositions is presented in supplementary data table 6 and in Fig. 5.

Anorthitic plagioclase $\left(A n_{95-85}\right)$ is the most common constituent of the cumulate xenoliths, ranging in modal proportion from $<1 \%$ to $\sim 70 \%$ and, with one exception (VS20), always above 40\%. Individual crystals are homogeneous, with slight reverse zoning present in only one of the samples studied (VS53), which had cores of $\sim A n_{90}$ and rims of $\sim A n_{93}$, a phenomenon also reported by Arculus and Wills (1980). Core-rim zoning in crystals from other samples is less than $1 \mathrm{~mol} \% \mathrm{An}$. The total range of compositions within each individual cumulate xenolith is generally very limited (maximum of $5 \mathrm{~mol} \%$ variation). Exceptions are samples VS48, VS36 and VS2A, which show zoning or two discrete plagioclase populations (see Table 1).

Olivine $\left(\mathrm{Fo}_{79-71}\right)$ is present in all samples with a range of modes from $<1 \%$ to $\sim 60 \%$. As with plagioclase, there 

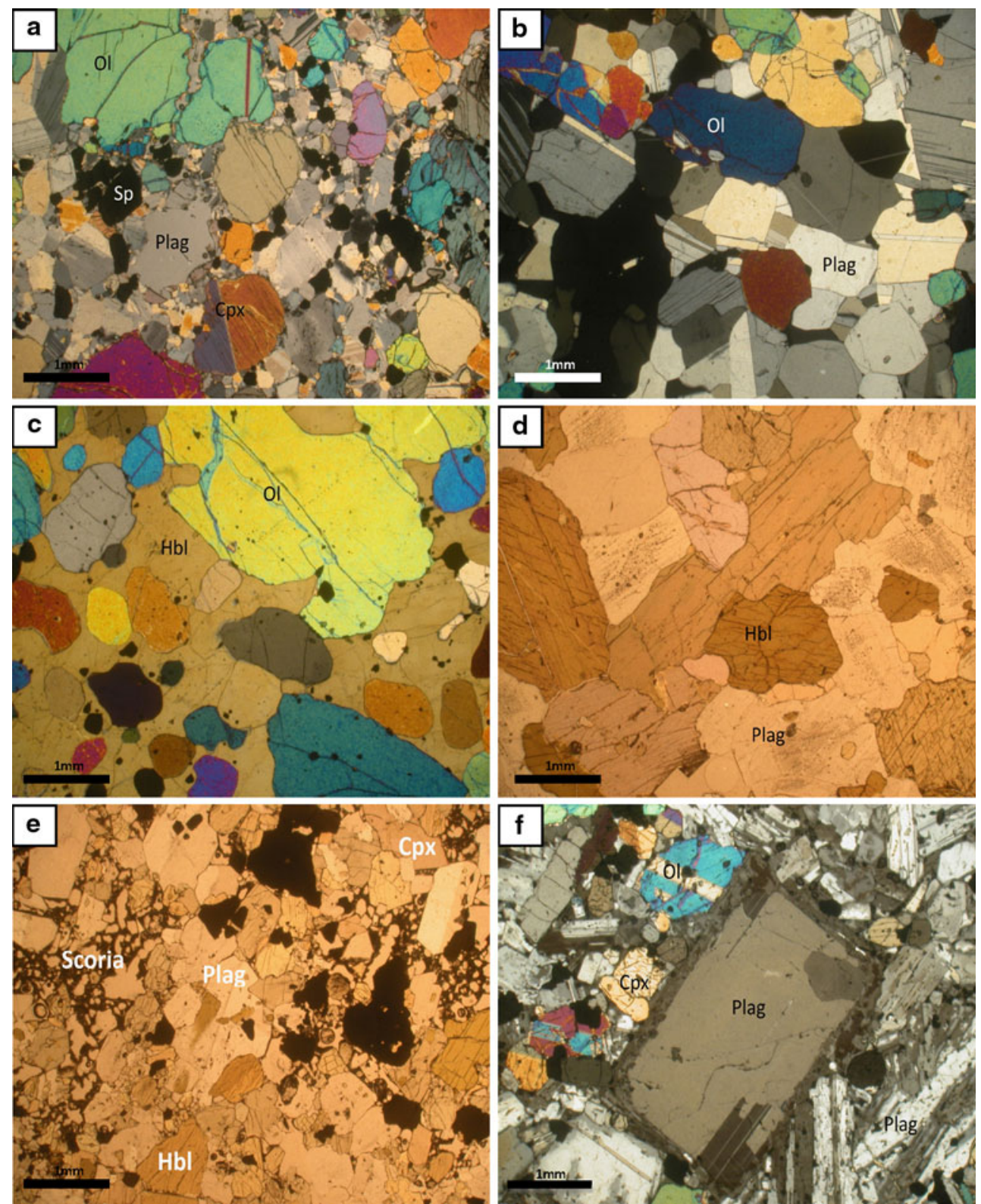

Fig. 3 Photomicrographs (crossed polars) of typical xenolith textures. a Sample VS2A. Olivine gabbro displaying orthocumulate texture. b VS14. Troctolite displaying adcumulate texture. c VS18. Hornblende oikocrysts encompassing olivine. d VS19. Olivine-

is essentially no variation in composition within each sample irrespective of crystal size with $\mathrm{Mg}-\mathrm{Fe}$ zoning never greater than 1 mol \% Fo. Ni concentrations range from 40 to $720 \mathrm{ppm}$ and correlate roughly with Fo. CaO content varied from 0.11 to $0.20 \mathrm{wt} \%$, which is a similar range to more primitive olivines reported by Bouvier et al. (2008). As with that study, we found no correlation between $\mathrm{CaO}$ and $F o$.

Clinopyroxene (Mg\# 81-75) is absent in three of the samples studied; the overall modal range is $0 \%$ to $\sim 50 \%$. Clinopyroxenes are high $\mathrm{Ca}, \mathrm{Al}$ and $\mathrm{Fe}^{3+} / \Sigma \mathrm{Fe}$ augites, with

hornblende gabbro displaying very well-equilibrated adcumulate texture. e VS46. Olivine-hornblende gabbro with heteradcumulate texture. Large dark areas are interstitial scoria. f VS48, displaying adcumulate texture and two distinct plagioclase populations

more heterogeneity displayed than the other main phases. Several samples, notably VS25A, VS46 and VS58, show both normal and reverse zoning of $\mathrm{Mg} \#$ and $\mathrm{Al}$. Noticeably, samples that show more $\mathrm{Al}$ zoning also have higher modal plagioclase (60 and $70 \%$ for VS46 and VS58, respectively).

Hornblende (Mg\# 89-79), approaching the magnesiohastingsite end member, is present in around half the samples, with modal abundance of $0-44 \mathrm{wt} \%$. Individual samples show heterogeneity in mineral chemistry from crystal to crystal, with some individual crystals showing 


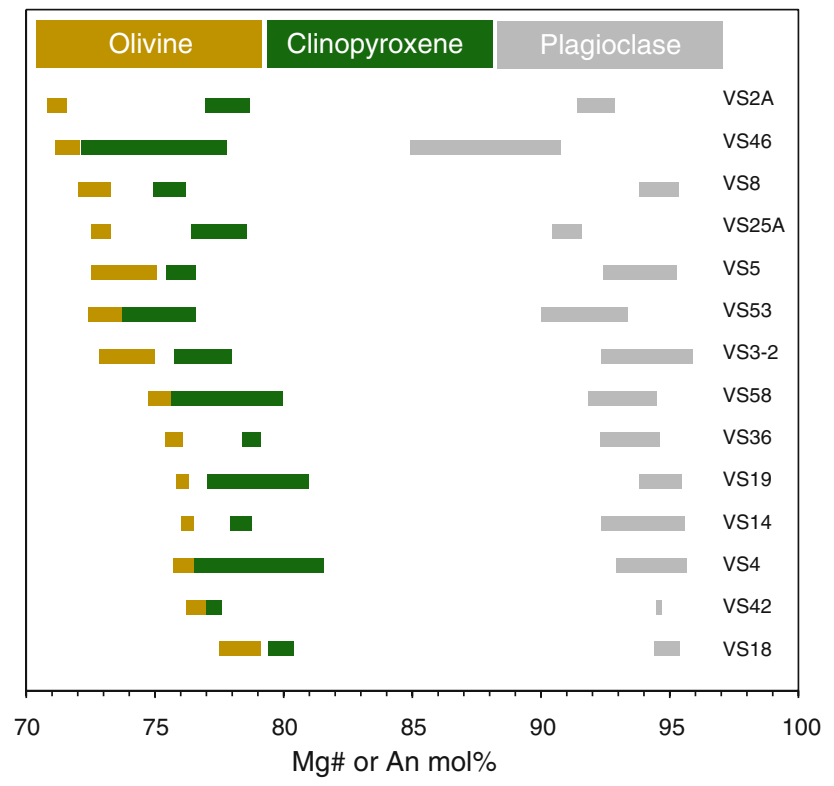

Fig. 4 Complete range of compositions (core and rim) of olivine, clinopyroxene and plagioclase of the cumulates in this study, arranged by olivine Fo content (highest at top). Rare but significant plagioclase zoning to low $A n$ contents or chemically distinct, $A n$-poor second populations (e.g. VS2A) are not plotted to maintain consistent scale (see text for details)

normal or, less commonly, reverse zoning of $\mathrm{Mg \#}$. As with the clinopyroxenes, hornblendes have high $\mathrm{Fe}^{3+} / \Sigma \mathrm{Fe}$ and high $\mathrm{Al}_{2} \mathrm{O}_{3}(>13 \mathrm{wt} \%)$. Hornblendes show no evidence of opacite rims, indicating that there was no significant breakdown during transport to lower pressures.

Two types of spinel were identified, although never coexisting in the same sample. The dominant spinel composition is high $\mathrm{Mg}$ and $\mathrm{Al}$ titanomagnetite, with $\mathrm{Cr} \# \ll 1$ and Mg\# 8-20 (Fig. 6a). $\gamma \mathrm{Cr}$ (15.4-0.1), $\gamma \mathrm{Al}(60.72-10.33)$ and $\gamma \mathrm{Fe}^{3+}\left(89.35-25.93\right.$ : where $\gamma^{\prime} \mathrm{X}^{\prime}={ }^{\prime} \mathrm{X}$ '/ $\Sigma^{\prime} \mathrm{X}$ ') are all consistent with values of typical island arc basalts (Eggins 1993) and overlap compositions from lavas (Fig. 6b). The second spinel type occurs uniquely in VS18, where it is the first mineral to crystallise. The composition is more primitive than the other samples, with Cr\# 14-24 and Mg\# 38-50, which corresponds well with the higher Mg\# of both olivine and clinopyroxene in the same sample.

Olivine and clinopyroxene compositions generally correlate well, with the exceptions of samples VS2A and VS46. The ratio between olivine and clinopyroxene $\mathrm{Mg \#}$ was fairly consistent throughout the entire range of samples, so was used to create fictive olivine or clinopyroxene compositions where that phase was missing, so as to enable direct comparison of all cumulates. Anorthite content of plagioclase correlates with olivine and pyroxene $\mathrm{Mg \#}$ (Fig. 8), although several samples show more evolved olivine coexisting with less evolved plagioclase (VS8) relative to other samples (Fig. 4). The most striking feature of

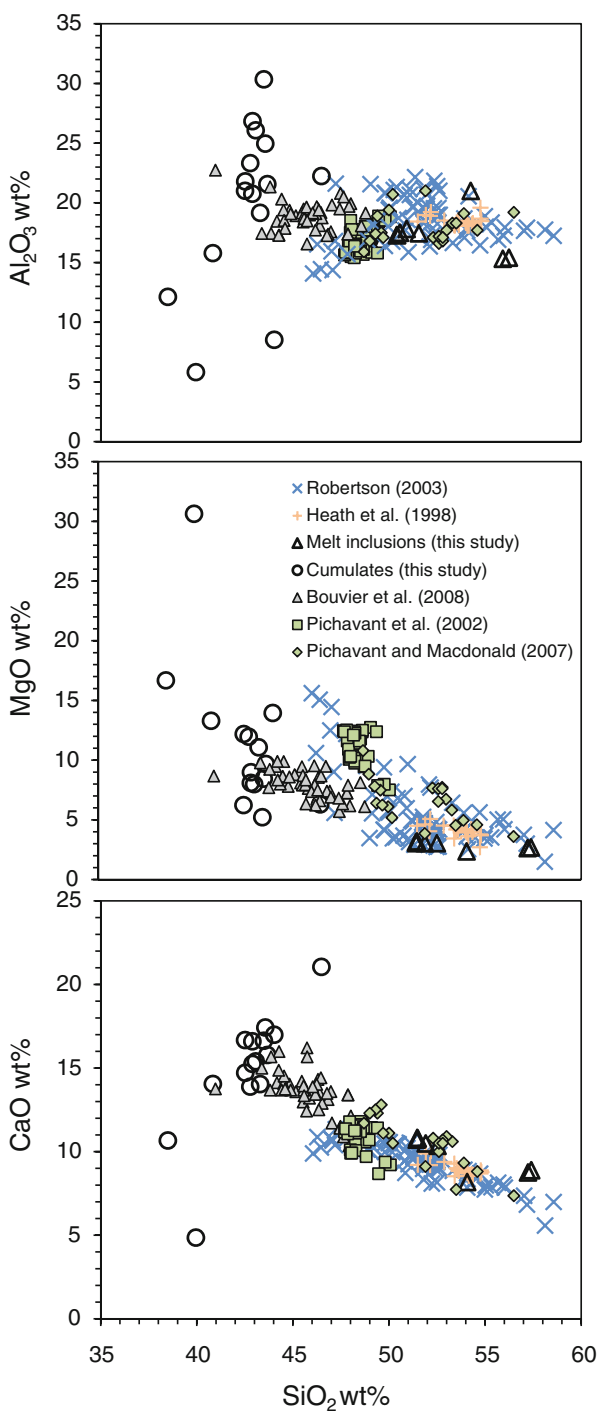

Fig. 5 Major element plots of St. Vincent lavas (Heath et al. 1998; Robertson 2003), melt inclusions (Bouvier et al. 2008), experimental melts (Pichavant et al. 2002; Pichavant and Macdonald 2007) compared to melt inclusions and bulk cumulates from this study. Bulk cumulate compositions were calculated from average mineral compositions and modes. Note that the majority of bulk cumulates fit well the liquid lines of descent defined by lavas and both natural and experimental melts

these cumulates, as previously recognised by Lewis (1973) and Arculus and Wills (1980), is the coexistence of An-rich plagioclase with substantially more evolved olivine.

\section{Melt inclusions}

Glassy melt inclusions (MI) were analysed in two samples: VS36 (olivine-hosted) and VS3-2 (hornblende-hosted). The olivine-hosted MI recorded low $\mathrm{Kd}_{\mathrm{Fe}-\mathrm{Mg}}$ values of $\sim 0.2$ and so were corrected for post-entrapment crystallisation (PEC) of olivine using the Petrolog software (Danyushevsky and Plechov 2011), assuming an equilibrium 
Fig. 6 a $\mathrm{Mg \#}$ and $\mathrm{Cr} \#$ $(100 \times \mathrm{Cr} / \mathrm{Cr}+\mathrm{Al})$ of spinel, clearly demonstrating the two distinct populations found in the cumulate xenoliths. Spinel derived from lavas (Heath et al. 1998) and experiments (Pichavant and Macdonald 2007) are plotted for comparison. b $\gamma \mathrm{Cr}, \gamma \mathrm{Al}$ and $\gamma \mathrm{Fe}^{3+}$ of cumulate, lava and experimental spinels. $\gamma \mathrm{X}=$ molar $\mathrm{X}^{3+} / \Sigma \mathrm{X}^{3+}$

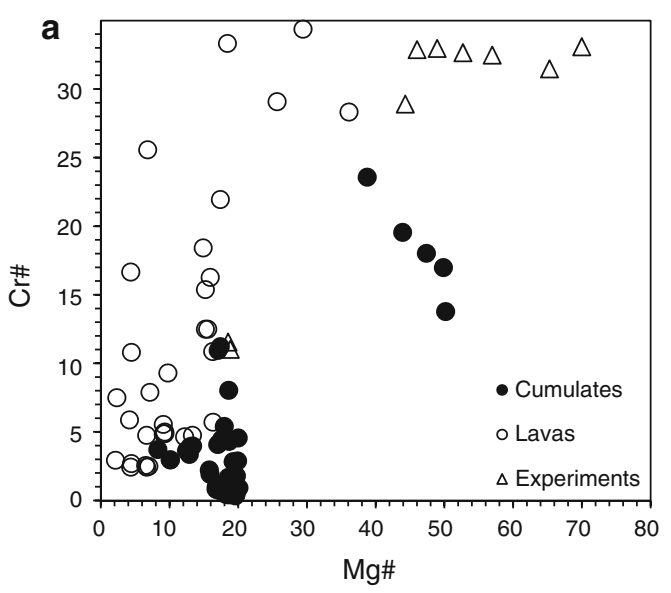

b

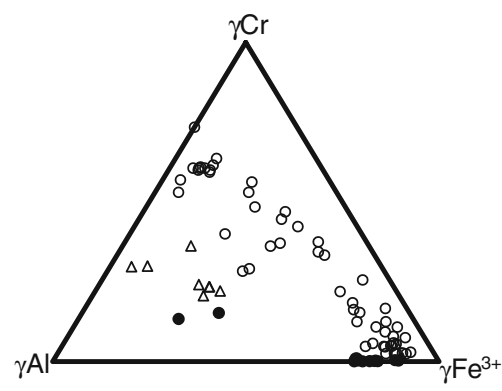

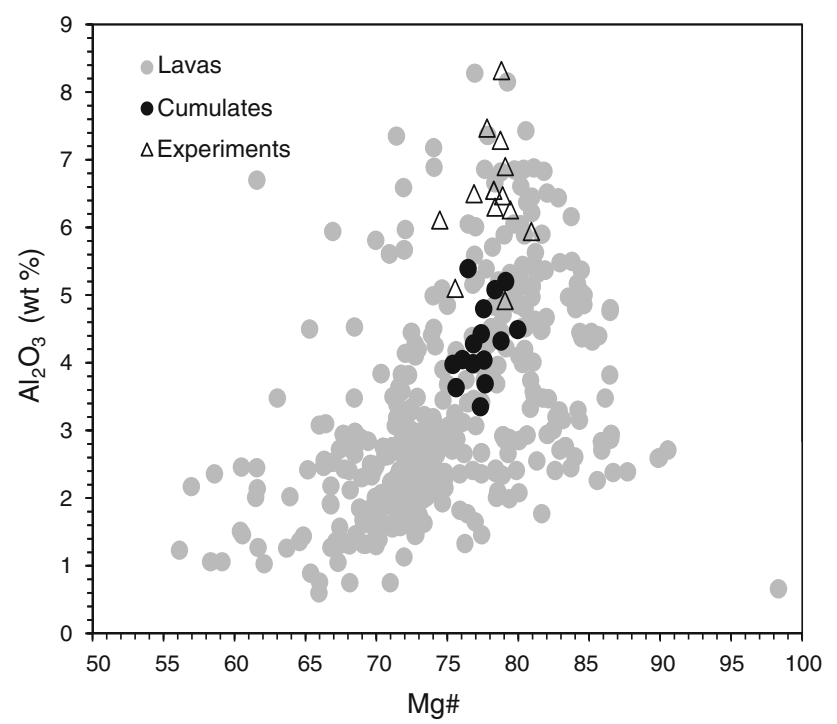

Fig. $7 \mathrm{Al}_{2} \mathrm{O}_{2}$ wt $\%$ versus $\mathrm{Mg} \#(100 \times \mathrm{Mg} / \mathrm{Mg}+\mathrm{Fe})$ for clinopyroxenes from cumulates, lavas (Robertson 2003) and experiments (Pichavant and Macdonald 2007)

$\mathrm{Kd}_{\mathrm{Fe}-\mathrm{Mg}}$ value of 0.3 and $\mathrm{FeO}=\mathrm{FeO}_{\text {Total }}$. $\mathrm{PEC}$ corrections were small, typically around $8 \%$. No attempt was made to correct the hornblende-hosted MI for post-entrapment crystallisation. Both uncorrected and corrected (olivinehosted) compositions are reported in supplementary data table 7. Further discussion of MI chemistry makes use of normalised (anhydrous) compositions.

Olivine-hosted MI from VS36 can be grouped into lowand high-silica groups $\left(\sim 51\right.$ and $\sim 56 \mathrm{wt} \% \mathrm{SiO}_{2}$, respectively). Low-silica MI contains up to $17.8 \mathrm{wt} \% \mathrm{Al}_{2} \mathrm{O}_{3}$ and $10 \mathrm{wt} \% \mathrm{CaO}$, whilst high-silica $\mathrm{MI}$ contains lower $\mathrm{Al}_{2} \mathrm{O}_{3}$ and $\mathrm{CaO}$ ( $\sim 15.4$ and $\sim 8.2$ wt $\%$, respectively). Both $\mathrm{MI}$ compositions are hosted by chemically identical olivines $\left(F_{75.7}\right)$, and have identical Mg\#s of 48 . The single hornblende-hosted MI analysis from VS3-2 has an intermediate silica content (54 wt \%) and high $\mathrm{Al}_{2} \mathrm{O}_{3}$ and $\mathrm{CaO}$ (20.9 and $8.2 \mathrm{wt} \%$, respectively) at a low $\mathrm{Mg \#} \mathrm{(29).}$
Comparison with St. Vincent lavas

The petrology and mineral chemistry of lavas and cumulates on St. Vincent are complementary, consistent with the cumulates being a subtractive (fractionating) assemblage in the petrogenesis of the lavas (Fig. 5). Heath et al. (1998) discuss in detail the geochemistry and petrography of lavas from both historical and pre-historical eruptions, which we summarise below.

Phenocryst mineral modes are generally similar to the cumulates, although the range is more restricted and consistent for each mineral phase in the lavas. The major differences between lavas and cumulates are the presence of orthopyroxene in the majority of lavas (although in small proportions) and the complete absence of hornblende. The lack of hornblende in lavas and its contrasting prevalence in cumulates is a well-known phenomenon, which can be attributed to low-pressure resorption of hornblende during magmatic ascent (Romick et al. 1992; Davidson et al. 2007; Larocque and Canil 2010).

Mineral compositions from lavas are often in contrast to cumulus minerals. Olivines in lavas are generally more forsteritic (up to $F_{O_{90}}$ ) and often display substantial normal zoning. Plagioclase is also normally zoned, from a maximum of $A n_{97}$ to a minimum of $A n_{46-}$. The prevalence of substantial zoning in phenocrysts demonstrates a much more complex growth history than the homogeneous cumulus minerals. Figure 8a plots olivine $(F o$ ) versus plagioclase $(A n)$ compositions for samples from cumulates, basaltic lavas (Robertson 2003) and experiments of Pichavant and Macdonald (2007; see below). The correlation between plagioclase and olivine composition in the cumulates is generally absent in the lavas. In general, lavas are displaced to higher $F o$ olivines coexisting with slightly lower $A n$ plagioclase, relative to cumulates. Additionally, there is considerable compositional zoning between cores and rims of phenocrysts within individual lavas, notably for plagioclase (Fig. 8) in contrast to the cumulates. 
Spinels in the lavas encompass a much greater compositional range in both $\mathrm{Mg \#}-\mathrm{Cr} \#$ and $\gamma \mathrm{Cr}-\gamma \mathrm{Al}-\gamma \mathrm{Fe}^{3+}$ space, which overlaps that defined by the most $\mathrm{Cr}$ - and $\mathrm{Mg}$-poor cumulus spinels (Fig. 6). The $\mathrm{Cr}$ spinels with low $\mathrm{Mg \#}$ from the lavas are absent from the cumulates ( $\mathrm{Cr} \# 35-85)$, whilst the more $\mathrm{Cr}$ - and $\mathrm{Mg}$-rich cumulus spinels plot as a distinct group remote from the lava compositions.

Clinopyroxene compositions in lavas are also similar to the cumulates, with high-Al augite prevalent in most of the lavas, occasionally with diopsidic cores (not found in the cumulates). The range of $\mathrm{Mg \#}$ for cpx is slightly greater in the lavas but encompasses the entire range reported here (Fig. 7).

\section{Comparison to experimental results}

An objective of this study was to assess whether the cumulates and lavas were derived from similar parental magmas and under similar crystallisation conditions. Pichavant and Macdonald (2007) conducted a series of equilibrium crystallisation experiments to constrain the $\mathrm{P}-\mathrm{T}-\mathrm{H}_{2} \mathrm{O}-\mathrm{fO}_{2}$ conditions, which produced the diversity of lava types erupted on the island. The two starting compositions used, STV301 and STV315, are representative of primary (high-magnesium basalt) and more evolved (basaltic andesite) lavas, respectively. Pressure was held at $4 \mathrm{kbar}$ for all but two of the experiments, which were at 10 kbar, whilst temperature, $\mathrm{H}_{2} \mathrm{O}$ and $\mathrm{fO}_{2}$ were varied to cover a range of realistic natural conditions.

Olivine compositions from the experimental results (Fig. 8a) were more forsteritic than the cumulus olivine (Fo90.5-75.7 compared to $\left.F_{O_{79-71}}\right)$. The only experiment with cumulus-like olivine compositions $\left(F_{o_{75.7}}\right)$ also contained orthopyroxene, which was essentially absent from the cumulate samples in this study. Experimental spinel was consistently more primitive than in cumulates, with

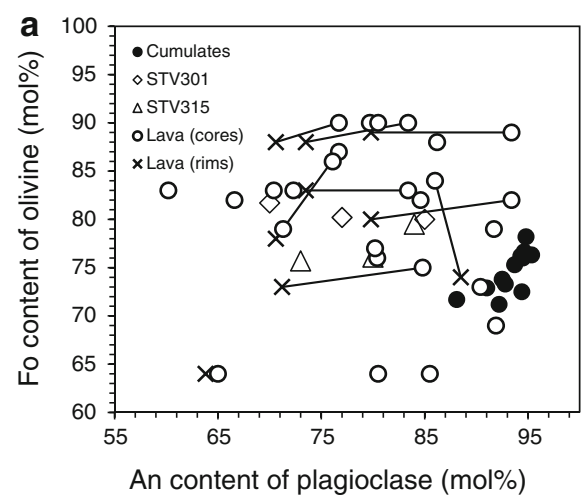

Fig. 8 Variation of olivine (a) and clinopyroxene (b) compositions with plagioclase compositions from cumulates in this study (filled circles), lava phenocrysts from Robertson (2003) (open circles and crosses) and experimental run products from basalt STV301 and much higher $\mathrm{Cr} \#$ (44-29) and $\mathrm{Al}_{2} \mathrm{O}_{3}$. The two experiments at $10 \mathrm{kbar}$, however, produced spinel compositions, which were a much closer match (Fig. 6). Experimental clinopyroxene compositions matched well with the samples in this study, although extended to higher $\mathrm{Al}_{2} \mathrm{O}_{3}$ (Fig. 7). Conversely, experimental plagioclase was appreciably less anorthitic than the cumulus plagioclase $\left(A n_{85-69}\right.$ compared to $A n_{95-85}$ ), despite the high experimental water contents. That the coexisting olivine and plagioclase compositions of individual cumulate xenoliths have not yet been reproduced experimentally is striking. Hornblende was only found in the 10-kbar runs. PEC-corrected MI compositions overlap the experimentally produced melts, with the main difference being lower $\mathrm{MgO}$ at a given $\mathrm{SiO}_{2}$ or $\mathrm{Al}_{2} \mathrm{O}_{3}$ content (Fig. 5). Through comparison of all phases, the experiment that produces compositions which most closely resemble the cumulates is run 4-3 (STV301, $4 \mathrm{kbar}$, $\left.1,050^{\circ} \mathrm{C}, 5.9 \mathrm{wt} \% \mathrm{H}_{2} \mathrm{O}, \Delta \mathrm{NNO}+0.4\right)$, although neither olivine nor plagioclase compositions fall quite within the cumulate range.

\section{Thermometry of cumulate assemblages}

Attempts to use mineral compositions to calculate equilibrium temperatures were restricted by a lack (or scarcity) of key phases, notably orthopyroxene, high-Cr spinel and coexisting $\mathrm{Fe}-\mathrm{Ti}$ oxide phases. Despite these limitations, three methods could be employed: the plagioclase-hornblende thermometer of Holland and Blundy (1994), the olivine-spinel $\mathrm{Fe}-\mathrm{Mg}$ exchange thermometer of Ballhaus et al. (1991) and the QUILF programme for equilibrium between $\mathrm{Fe}-\mathrm{Mg}$ silicates and oxides (Anderson et al. 1993). The temperatures obtained using the plagioclasehornblende thermometer, for touching mineral pairs, were $980-1,020^{\circ} \mathrm{C}$, which is consistent with the late appearance of hornblende in the crystallisation sequence. A problem

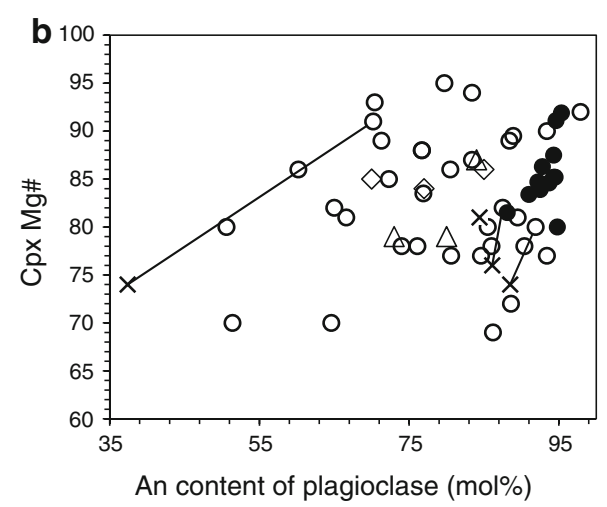

basaltic andesite STV315 (Pichavant and Macdonald 2007). Phenocrysts cores and rims joined by a line denote zoning in a single sample. Note different horizontal scales in $\mathbf{a}$ and $\mathbf{b}$ 


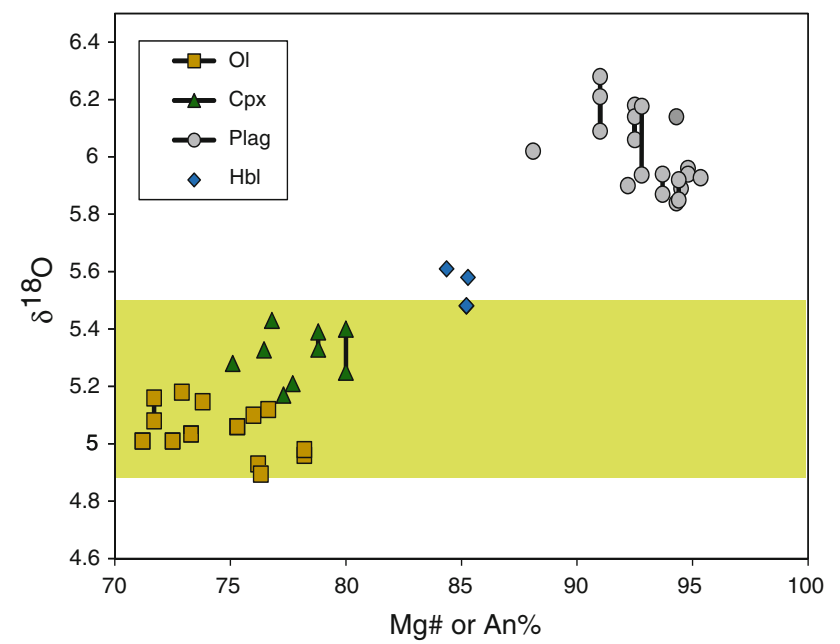

Fig. $9 \delta^{18} \mathrm{O}$ of olivine, clinopyroxene, plagioclase and hornblende plotted against their respective Mg\# or mol\% An. Symbols connected by a line denote repeat analyses of samples from the same rock. Shaded area is the mantle range for olivine $\delta^{18} \mathrm{O}$ (Mattey et al. 1994)

with this thermometer is that the most anorthitic plagioclase that can be used in calculating a temperature is $A n_{90}$ (Holland and Blundy 1994). As all but one sample contained plagioclase more anorthitic than this, other calculations had to be performed using a slightly less anorthitic value, which will have introduced a slight (underestimate) error to the results. The olivine-spinel $\mathrm{Fe}-\mathrm{Mg}$ exchange thermometer is only applicable at higher spinel $\mathrm{Cr}$; therefore, we could only obtain one temperature using this method, for sample VS18. The calculated temperature was $1,066^{\circ} \mathrm{C}$, which is within the range calculated by Heath et al. (1998) for primitive St. Vincent basalts using the same method $\left(1,026-1,147^{\circ} \mathrm{C}\right)$. The calculated temperature is $\sim 140^{\circ} \mathrm{C}$ lower than the experimentally derived liquidus for $\mathrm{HMB}$ at 4 kbar for any reasonable $\mathrm{H}_{2} \mathrm{O}$ content (Fig. 10; Pichavant and Macdonald 2007). However, given both the experimental products and analysed lavas are more primitive than VS18 (in particular the higher Cr\# of spinel), lower temperature crystallisation may be anticipated. Using QUILF (Anderson et al. 1993), a two-pyroxene temperature was calculated for VS2A (the only sample with orthopyroxene) of $970^{\circ} \mathrm{C}$, which is consistent with the late crystallisation of orthopyroxene seen in experiments (Pichavant and Macdonald 2007) and inferred from textural observations. For all three mineral thermometers, a pressure of $5 \mathrm{kbar}$ was assumed, although varying pressure in the temperature calculation only had a small effect.

We conclude that, although the cumulate assemblages at St. Vincent are broadly consistent with basalt crystallisation at mid-crustal pressures, the exact conditions in $\mathrm{P}-\mathrm{T}-$ $\mathrm{H}_{2} \mathrm{O}-\mathrm{fO}_{2}$ space have eluded experimental reproduction. The possibility that fractional crystallisation, rather than equilibrium crystallisation (as simulated experimentally), played a key role in generating the cumulates remains to be tested.

\section{Results}

Oxygen and hydrogen isotope results are reported in Table 2, and oxygen isotope values are plotted in Fig. 9, expressed in the standard delta notation, relative to Vienna Standard Mean Ocean Water (VSMOW).

Table 2 Oxygen and hydrogen isotope results (per mil) relative to VSMOW. $\delta^{18} \mathrm{O}_{\text {Melt }}$ was calculated using the method described in the text, using the melt inclusion compositions of VS36 and VS3-2. Note the much greater variation in repeat analyses of plagioclase over olivine. Numbers in brackets denote number of grains for each analysis

\begin{tabular}{|c|c|c|c|c|c|c|c|c|}
\hline Sample & $\mathrm{Ol}$ & Cpx & Plag & $\mathrm{Hbl}$ & $\begin{array}{l}\text { Melt } \\
\text { (VS36) }\end{array}$ & $\begin{array}{l}\text { Melt } \\
\text { (VS3-2) }\end{array}$ & $\delta \mathrm{D}_{\mathrm{Hbl}}$ & $T\left({ }^{\circ} \mathrm{C}\right)$ \\
\hline VS2A & $5.01(1)$ & $5.21(2)$ & $5.9(1)$ & & 5.86 & 5.94 & & 1134 \\
\hline VS3-2 & & & $6.14(1)$ & $5.61(2)$ & & & -43.4 & \\
\hline VS4 & $4.89(1)$ & $5.32(2)$ & $5.93(1)$ & & 5.90 & 5.99 & & 1021 \\
\hline VS8 & $5.01(1)$ & & $5.85(2), 5.92(2)$ & $5.58(3)$ & 5.85 & 5.93 & -38.9 & 1166,1109 \\
\hline VS14 & $4.93(1)$ & & $5.84(2)$ & & 5.81 & 5.89 & & 1110 \\
\hline VS18 & $4.96(1), 4.98(1)$ & $5.25(3), 5.4(4)$ & $5.94(6), 5.96(4)$ & $5.48(2)$ & $5.91,5.93$ & $6.00,6.02$ & -35.5 & 1071,1044 \\
\hline VS19 & $5.1(2)$ & $5.33(2), 5.39(1)$ & 5.89 & & 5.86 & 5.93 & & 1210 \\
\hline VS20 & $5.15(1)$ & $5.43(1)$ & $6.06(1), 6.14(3), 6.18(7)$ & & & 6.17 & -49.1 & $1115,1058,1032$ \\
\hline VS25A & $5.18(3), 5.18(1)$ & $5.17(2)$ & $6.09(1), 6.21(1), 6.28(2)$ & & 6.12 & 6.21 & & $1123,1040,997$ \\
\hline VS42 & $5.12(2)$ & $5.33(1)$ & & & & & & \\
\hline VS46 & $5.08(4), 5.16(3)$ & $5.28(4)$ & $6.02(4)$ & & $5.91,5.99$ & $5.99,6.07$ & -37.2 & 1176,1113 \\
\hline VS53 & 5.03 & & $5.94(3), 6.18(2)$ & & 5.90 & 5.99 & & 1121,967 \\
\hline VS58 & $5.06(1)$ & $5.22(1), 5.47(1)$ & $5.87(2), 5.94(1)$ & & 5.87 & 5.95 & -49.9 & 1195,1136 \\
\hline
\end{tabular}


Olivine

For the range of cumulates studied, $\delta^{18} \mathrm{O}_{\text {Olivine }}$ varied from 4.89 to $5.18 \%$ o $(n=15)$. These values fall towards the low end of the range for olivines from mantle peridotite xenoliths (4.82-5.50\%; Mattey et al. 1994; Fig. 8). Within-sample variation was low, with repeat analyses on different days giving reproducibility of $\pm 0.00-0.06 \%$.

\section{Clinopyroxene}

$\delta^{18} \mathrm{O}_{\mathrm{Cpx}}$ varied from 5.17 to $5.47 \%$ with an average value of $5.32 \pm 0.09 \%$ o $(n=12)$. This falls towards the low end of the range for clinopyroxene in equilibrium with the mantle (5.25-5.90\%; Mattey et al. 1994), with three samples (VS2a, VS25a and VS58) falling outside this range. It should be noted, however, that the composition of the clinopyroxene is quite different to typical mantle clinopyroxene, particularly the much higher $\mathrm{Al}$ and $\mathrm{Fe}^{3+}$ (Kohn and Valley 1998). Sample reproducibility was somewhat worse than that obtained for the olivine results, with a variation of up to $0.15 \%$ o during a single analytical session (sample VS18), which can be attributed mainly to problems in achieving complete vaporisation during lasing and/or unseen mineral inclusions (Harris et al. 2000).

\section{Plagioclase}

The range of $\delta^{18} \mathrm{O}_{\mathrm{Plag}}$ was 5.84-6.28\%o with an average of $6.01 \pm 0.13 \%$ o $(n=20)$. Variation within single cumulates was observed in both small (0.02-0.05\%) and large $(0.12-0.19 \%$ ) ranges, irrespective of whether the analyses were done on the same day or on different days. In samples with different populations of plagioclase crystals, there was significant variability. In particular, the two distinct and separable size populations in VS53 gave contrasting values of 5.94\%o and 6.18\% for small and large grains, respectively. Standard accuracy during this analytical session was $\pm 0.06 \%$, which shows that the observed variations in samples are not due to analytical error. This isotopic heterogeneity may be due to contrasting anorthite content of the small and large grains, although our limited probe analyses for this sample showed no significant intercrystal variation.

\section{Hornblende}

Three hornblende oxygen isotope analyses give a range of 5.48-5.61\%. Despite the small number of analyses, they provide an indication of the magnitude of the equilibrium fractionations between hornblende of this composition and other phases. Six samples were also analysed for hydrogen isotopes, with each sample duplicated to check reproducibility and within-sample variation. The range of $\delta \mathrm{D}$ values obtained was -35.2 to $-51.3 \%$, with an average of $-42.3 \%$. Three samples varied very little between analyses $(1 \sigma<1 \%$, whilst the other three samples showed much more variation $(1 \sigma 2.2-4.3 \%$ ). All samples are isotopically heavier than the normal mantle $\delta \mathrm{D}$ value of $-80 \pm 10 \%$ (Kyser and O'Neil 1984) but consistent with the values reported for bulk hornblendes from Montserrat in the Lesser Antilles (average value of $-38 \pm 12 \%$; Harford and Sparks 2001).

Isotopic fractionations and geothermometry

The sense of oxygen isotope fraction between plagioclase and olivine $\left(\Delta_{\text {Plag-ol }}=\delta^{18} \mathrm{O}_{\mathrm{Plag}}-\delta^{18} \mathrm{O}_{\mathrm{Ol}}\right)$ is consistent with magmatic values for all samples and varies from 0.79 to $1.10 \%$ (Fig. 10). Using these fractionations, isotopic equilibrium temperatures were calculated utilising the temperature equation and coefficients from Chiba et al. (1989). This gave a temperature range of $997-1,210^{\circ} \mathrm{C}$ (Fig. 10), which is consistent with the experiments of Pichavant and Macdonald (2007), where plagioclase cocrystallised with olivine over a temperature range of $1,050-1,150^{\circ} \mathrm{C}$ at different water contents. However, hornblende-plagioclase thermometry demonstrates that temperatures subsequently dropped below that of initial plagioclase saturation $\left(\sim 1,000^{\circ} \mathrm{C}\right)$. That $\Delta_{\text {Plag-ol values do }}$ not record this lower temperature in the majority of cases

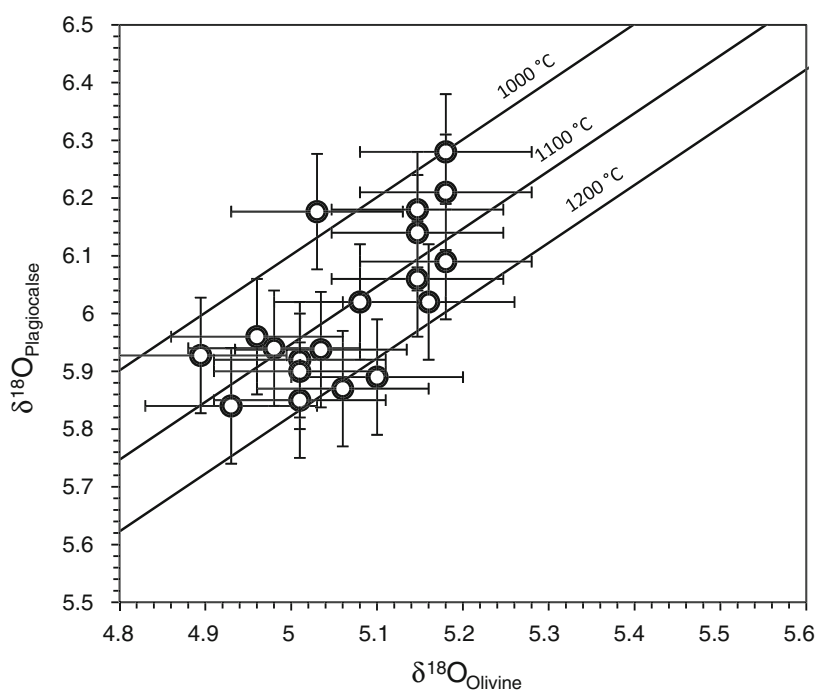

Fig. 10 Oxygen isotope composition of coexisting plagioclase and olivine. Lines represent isotopic temperatures calculated from the fractionation between plagioclase $\left(A n_{90}\right)$ and olivine, using the fractionation factors from Chiba et al. (1989). All plagioclase-olivine temperatures are higher than those calculated from amphiboleplagioclase and 2-pyroxene pairs (see text). Error bars are average 1 SD from repeat analysis of standards 
indicates cooling rates and residence times were insufficient to achieve full re-equilibration through diffusion and may demonstrate 'protocrystic' behaviour as described by Bindeman (2008), and discussed later.

Isotopic fractionations and, consequently, calculated temperatures involving clinopyroxene were inconsistent and showed no correlation between $\delta^{18} \mathrm{O}_{\mathrm{Cpx}}$ and $\delta^{18} \mathrm{O}_{\text {Plag }}$ or $\delta^{18} \mathrm{O}_{\mathrm{Ol}}$. We attribute this to known analytical difficulties associated with clinopyroxene (especially high $\mathrm{Al}$ contents), as noted earlier, and therefore make no further interpretation of the clinopyroxene analyses.

$\delta^{18} \mathrm{O}_{\text {Melt }}$ calculation

Calculating the oxygen isotope composition of melt in equilibrium with minerals of known isotopic composition is an important step in assessing potential variation resulting from crustal contamination or fractional crystallisation. Oxygen isotope fractionation between mineral and melt is dependent on the chemical composition of the mineral and of the melt (Eiler 2001; Zhao and Zheng 2003; Bindeman et al. 2004), so selecting an appropriate melt composition is essential. Due to the difficulty in determining exact melt compositions from which a particular cumulate crystallised, the same composition was used for all calculations. However, as the cumulates exhibit significant variation in mineral mode, this will produce uncertainty in nearly all calculations. The method used is detailed in Bindeman et al. (2004) and in the modelling section of the discussion below. The fractionation between melt and olivine was chosen due to the slow diffusion of oxygen in olivine, relative to plagioclase, making it more likely to reflect original magmatic values (Eiler et al. 2000). Temperature was taken from the average isotopic fractionation between plagioclase and olivine for each sample. The average of the more primitive olivine-hosted MI compositions from VS36 (51.8 wt\% $\mathrm{SiO}_{2}$ ) and the single hornblende-hosted MI composition from VS3-2 (54.1 wt $\% \mathrm{SiO}_{2}$ ) was used to represent primitive and evolved cumulate-derived melts, respectively. The more evolved MI composition from VS36 was not used, since it is in equilibrium with much less anorthitic plagioclase than the cumulus plagioclase (based on application of the melt-plagioclase geothermobarometer of Putirka (2005), using realistic magmatic parameters). Calculated $\delta^{18} \mathrm{O}_{\text {Melt }}$ values ranged from 5.81-6.12\% to 5.89-6.21\%o, for more primitive and evolved melt compositions, respectively, with an average difference between the two melt compositions of $0.08 \%$. This overlaps the range of primary mantle-derived melts $(5.7 \pm 0.2 \%$; Harmon and Hoefs 1995) but is consistently at the high end of the range, reflecting the more evolved melt compositions involved in cumulate petrogenesis. The true $\delta^{18} \mathrm{O}_{\text {Melt }}$ value for each sample is assumed to be intermediate between the two calculated values.

\section{Discussion}

Crustal contamination

A key question to address is whether crustal contamination is an important process on St. Vincent, as it is on many other islands in the Lesser Antilles (Davidson and Harmon 1989; Smith et al. 1996; Thirwall et al. 1996; Harford and Sparks 2001; Van Soest et al. 2002; Zellmer et al. 2003). Due to the typically contrasting isotopic composition of crust and mantle-derived magmas (Bindeman 2008), the mixing of the two components, either by bulk assimilation or partial melting, can have a significant and easily detectable impact on the oxygen and hydrogen isotope compositions of both melt and precipitating minerals (James 1981; Davidson and Harmon 1989; Feeley and Sharp 1995; Harford and Sparks 2001; Widom and Farquhar 2003; Garcia et al. 2008; Bolhar et al. 2008). Van Soest et al. (2002) found a relatively large range of $\delta^{18} \mathrm{O}_{\text {Olivine }}$ values $(4.74-5.36 \%$ ) for lava-hosted phenocrysts and concluded that the lowest of these values required the addition of low $\delta^{18} \mathrm{O}$, hydrothermally altered crust during magmatic evolution. The $\delta^{18} \mathrm{O}_{\text {Olivine values }}$ from our study cover a narrower range (4.89-5.18\%), within the total spectrum of mantle olivines (Mattey et al. 1994). $\delta^{18}$ OPlagioclase values (5.84-6.28) are also consistent with crystallisation from an uncontaminated magma source, once the highly anorthitic composition is taken into account. Likewise, the hydrogen isotope composition of hornblende covers a broad range of values $(-51.3$ to $-35.2 \%$ ), which is similar to values typical of arc magmas (Harford and Sparks 2001; Shaw et al. 2008). We therefore preclude assimilation of isotopically distinct crust as a major process in the genesis of the cumulates. However, minor amounts of assimilation of arc crust with similar $\delta^{18} \mathrm{O}$ values to the crystallising melt could explain the diversity of values measured. This is plausible given the hypothesised cumulate-rich/basaltic nature of arc crust at St. Vincent (Arculus and Wills 1980), such that re-melting of, or equilibration with, the previous cumulate deposits of contrasting modal mineralogy following fresh injections of magma could modify $\delta^{18} \mathrm{O}$ of melt and crystallising minerals. For example, assimilation of a plagioclase-dominated cumulate assemblage into a more mafic magma would raise the $\delta^{18} \mathrm{O}$ without impacting significantly the melt $\mathrm{Mg}$. Dungan and Davidson (2004) have suggested that cumulate assimilation is a widespread process beneath arc volcanoes. A thorough radiogenic isotope and trace element study of 
cumulate xenoliths is required to further constrain the role of such assimilation processes on St. Vincent.

Fractional crystallisation

Closed system (i.e. assimilation-free) fractional crystallisation of primitive magmas can generate subpermil increases in the $\delta^{18} \mathrm{O}$ of melt due to increases in $\mathrm{SiO}_{2}$ content and the removal of isotopically light mafic mineral phases (Eiler et al. 2000; Harris et al. 2000; Bindeman et al. 2004; Cooper et al. 2004; Valley et al. 2005; Bolhar et al. 2008). Previous modelling of the change in isotopic composition of melt during magmatic differentiation has demonstrated an important mineral control on the precise trajectory taken (Macpherson and Mattey 1998; Bindeman et al. 2004; Cooper et al. 2004). Initial crystallisation of olivine, spinel and pyroxene drives the $\delta^{18} \mathrm{O}$ of melt to more positive values. Appearance of plagioclase, which is unique in mafic magmas in being the only phase which is isotopically heavier than the coexisting melt, tends to flatten out the $\delta^{18} \mathrm{O}$ trajectory of the melt, with the modal ratio of plagioclase to coprecipitating olivine, pyroxene and spinel dictating to what degree the $\delta^{18} \mathrm{O}$ curve becomes flattened.

In arc magmas, the appearance and modal proportion of plagioclase in the crystallising assemblage vary greatly as a function of the water content of the magma (Sisson and Grove 1993; Grove et al. 2003; Pichavant and Macdonald 2007; Feig et al. 2010). Therefore, variations in the oxygen isotope composition of evolving arc magmas may be anticipated due to variations in water content. Bouvier et al. (2008) found significant variations in the water content of olivine-hosted melt inclusions (0.9-3.5 wt\% $\mathrm{H}_{2} \mathrm{O}$ ) from lavas inferred to be near primary. This would suggest that a lot of the chemical variability observed in erupted lavas may be explained by different differentiation pathways controlled in part by the $\mathrm{H}_{2} \mathrm{O}$ content of primary melts, which in turn influences the point of plagioclase saturation relative to mafic minerals. A key question then is whether the cumulates in this study could be derived from a single primary melt and, if not, whether variations in $\mathrm{H}_{2} \mathrm{O}$ content alone can explain the diversity of isotopic values.

In a single evolving magma, the modal proportion of olivine should decrease as a function of differentiation, whereas plagioclase, once saturated, would be expected to increase. However, the modal proportions of all minerals, particularly hornblende, in St. Vincent cumulates show no systematic variation with mineral composition (Fig. 2). The appearance of plagioclase in the crystallisation sequence also varies (Table 3), appearing later in cumulates containing hornblende, and covers a wide range of temperatures, as demonstrated by the range of $\Delta_{\text {Plag-ol }}$ values (Fig. 10). This supports the idea that $\mathrm{H}_{2} \mathrm{O}$ content varied in the parental magmas to these cumulates, as $\mathrm{H}_{2} \mathrm{O}$ exerts a significant control on crystallisation of both plagioclase and hornblende. The lack of correlation between mineral compositions and the large modal variations further suggests that these cumulates do not share a common magmatic lineage. The $\delta^{18} \mathrm{O}$ values for olivine and plagioclase are spread over a relatively narrow range of chemical compositions $\left(F o_{79-71}\right.$ and $\left.A n_{95-85}\right)$ but show no significant correlation with $\mathrm{Mg \#}$ or $A n$ content (Fig. 9). Given that fractional crystallisation can typically increase the $\delta^{18} \mathrm{O}$ of melt by no more than $0.15-0.2 \%$ for basalts (Bindeman et al. 2004; Cooper et al. 2004), it is unlikely that fractional crystallisation of a single magma with a given $\mathrm{H}_{2} \mathrm{O}$ content could produce the observed range in isotopic composition. The variation in the hydrogen isotope composition of hornblende is similarly diverse, given its narrow range of Mg\# (89-79). In the absence of crustal contamination, an additional process must be involved to create the observed variability. Given the highly equilibrated textures of most
Table 3 Crystallisation histories constructed through petrographic observation of included mineral phases.

Separation by a comma denotes both minerals included in each other (co-precipitation). Note preponderance for plag to either crystallise after cpx or be completely absent in samples with hbl present and vice versa

\begin{tabular}{lllll}
\hline Sample & 1 & 2 & 3 & 4 \\
\hline VS2A & Ol, Plag & Cpx & Sp \\
VS3-2 & Plag, Cpx & Sp & Hbl \\
VS8 & Ol, Plag & Hbl & \\
VS11 & Ol & Plag & Cpx \\
VS14 & Ol & Plag & Cpx & Hbl \\
VS16 & Ol, Cpx & Sp & Plag & Hbl \\
VS18 (Layer 1) & Sp & Ol & & \\
VS18 (Layer 2) & Plag & Cpx & Hbl & Cpx \\
VS19 & Ol, Cpx & Plag & Hbl & \\
VS20 & Ol, Sp & Cpx & Sp \\
VS25A & Ol & Plag & Cpx \\
VS36 & Ol, Plag & Plag & \\
VS58 & Ol & & \\
\hline
\end{tabular}


samples, the lack of significant zoning in plagioclase and the pristine appearance of the cumulus hornblende, it is unlikely the parental magmas experienced any degassing or heating-induced dehydrogenation, both of which are known to fractionate hydrogen isotopes (Harford and Sparks 2001). Instead, variations in $\mathrm{H}_{2} \mathrm{O}$ content and consequently $\mathrm{fO}_{2}$ provide a more likely explanation, through isotopic fractionation generated by varying amounts of the oxy-amphibole component (Clowe et al. 1988).

\section{Modelling}

In order to test the effect of $\mathrm{H}_{2} \mathrm{O}$ on $\delta^{18} \mathrm{O}$ during magmatic evolution, the results of crystallisation experiments on St. Vincent basalts from Pichavant and Macdonald (2007) were used to model $\delta^{18} \mathrm{O}$ changes during fractional crystallisation for melts with $\sim 4.5 \mathrm{wt} \%$ and $\sim 3.1 \mathrm{wt} \% \mathrm{H}_{2} \mathrm{O}$. Fractional crystallisation was favoured over equilibrium crystallisation principally because cumulus mafic mineral compositions, in particular olivine, extend to much more evolved (low Mg\#) values than those produced under equilibrium crystallisation experiments despite the low melt fractions $(F)$ involved $(F \geq 0.39$ ). This extension of mineral compositions to low $\mathrm{Mg \#}$ under fractional crystallisation conditions is clearly demonstrated by the experiments of Villiger et al. (2004). The method of modelling is described in detail in the Supplementary Information.

The trends for $\delta^{18} \mathrm{O}_{\text {Melt }}$ (Fig. 11) are consistent with the previous model curves calculated using the MELTS algorithm (Cooper et al. 2004; Bindeman et al. 2004). For an initial melt with $\sim 3.1 \mathrm{wt} \% \mathrm{H}_{2} \mathrm{O}$, the increase in $\delta^{18} \mathrm{O}$ over the total amount of crystallisation modelled $(F=0.53)$ is $0.24 \%$. Whilst these model curves encompass or approach the majority of $\delta^{18} \mathrm{O}_{\text {Melt }}$ estimates, using the more evolved melt chemical composition, there are a number of values that drop below the model trajectories. However, it is likely that primary melts at St. Vincent with lower initial water contents exist (Pichavant et al. 2002; Bouvier et al. 2008). These drier melts would produce a more significant deflection in $\delta^{18} \mathrm{O}_{\text {Melt }}$ trajectory, explaining the slightly lower $\delta^{18} \mathrm{O}_{\text {Melt }}$ estimates for these cumulates.

The modelled trends for $\delta^{18} \mathrm{O}_{\text {Olivine }}$ versus $\mathrm{Mg \#}$ (Fig. 11) both show $\delta^{18} \mathrm{O}$ decreasing during fractional crystallisation. The effect of fractional crystallisation on $\delta^{18} \mathrm{O}_{\text {Olivine between }} \mathrm{Fo}_{90}$ and $\mathrm{Fo}_{70}$ is $0.1 \%$ at $\sim 4.5 \mathrm{wt} \%$ $\mathrm{H}_{2} \mathrm{O}$ and $0.17 \%$ at $\sim 3.1 \mathrm{wt} \% \mathrm{H}_{2} \mathrm{O}$, which is a more restricted isotopic range than for $\delta^{18} \mathrm{O}_{\text {Melt }}$. This demonstrates a further competition between $\delta^{18} \mathrm{O}$ increase in the melt during magmatic evolution and the associated decrease in the temperature of the system. The rate of cooling during crystallisation is high enough that the increase in fractionation between olivine and melt is greater than the increase in $\delta^{18} \mathrm{O}_{\text {Melt }}$ resulting in the

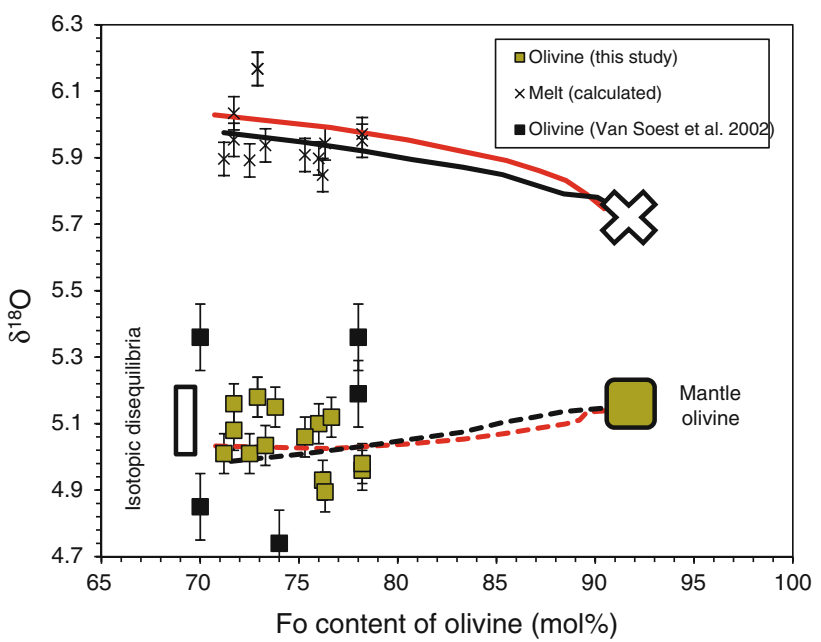

Fig. 11 Change in $\delta^{18} \mathrm{O}$ of olivine and melt during closed system (i.e. assimilation-free) fractional crystallisation of high-magnesium basalt STV301. Fractional crystallisation paths are modelled using the compositional and experimental data from Pichavant and Macdonald (2007) and the method described in the text. Red and black lines are for primary melts with initially 3.1 and $4.5 \mathrm{wt} \% \mathrm{H}_{2} \mathrm{O}$, respectively, which display slightly different crystallisation sequences. Also plotted are the analysed olivines and calculated melts from this study and the analysed olivines from Van Soest et al. (2002). Error bars for olivines are based on the average analytical error on repeat analyses $(1 \sigma)$. Error bars on calculated $\delta^{18} \mathrm{O}_{\text {Melt }}$ embrace the likely effect of melt composition from more primitive to more evolved (see text for full explanation). Fractional crystallisation of a parent melt with a single $\delta^{18} \mathrm{O}$, but variable $\mathrm{H}_{2} \mathrm{O}$, cannot account the observed spread in olivine $\delta^{18} \mathrm{O}$

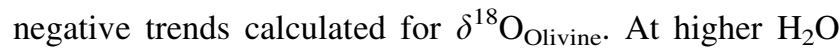
contents, the greater initial increase in $\delta^{18} \mathrm{O}_{\text {Melt }}$ is compensated by the lower liquidus temperatures (larger isotopic fractionations), resulting in the crystallisation of lower $\delta^{18} \mathrm{O}$ olivines. As observed in the experiments of Pichavant and Macdonald (2007), the drop in temperature during crystallisation is smaller at higher $\mathrm{H}_{2} \mathrm{O}$ contents which, combined with the suppression of plagioclase, results in an overall shallower trajectory and a crossover with the lower water content model trend at around $\mathrm{Fo}_{78}$. Therefore, the total variation in $\delta^{18} \mathrm{O}_{\text {Olivine values that can be expected to }}$ be produced by simply varying parental water content is less than $0.1 \%$. This falls short of the total range of $\delta^{18} \mathrm{O}$ values for cumulus olivine $(0.29 \%$ ).

In summary, crystallisation of a parent magma with a single oxygen isotope composition, but variable $\mathrm{H}_{2} \mathrm{O}$, cannot generate the observed oxygen isotope diversity of St. Vincent cumulates. We next consider the extent to which isotopic disequilibrium within a cooling cumulate could generate isotopic variability.

Protocrystic olivine and isotopic disequilibria

An important observation when comparing the measured $\delta^{18} \mathrm{O}_{\text {Olivine values with the modelled values is that the }}$ 
cumulus olivines have consistently higher $\delta^{18} \mathrm{O}$ than model values at equivalent $\mathrm{Mg \#}$ (up to $0.2 \%$; Fig. 11 ). We interpret this discrepancy between measured and calculated values to reflect 'protocrystic' behaviour of olivine, as described by Bindeman (2008). In slow cooling magmatic systems, the slower diffusion of oxygen in olivine compared with plagioclase can impede equilibration between the two phases. Olivine crystallised at higher temperatures will retain the original magmatic value as the residual melt evolves, as long as the cooling rate is more rapid than the timescales required for isotopic re-equilibration for a particular grain size. The process of diffusive re-equilibration is arrested by the entrainment and eruption of the olivineplagioclase pair. In the light of this, isotopic temperatures calculated using plagioclase and olivine must be interpreted to reflect a value intermediate between the liquidus temperature and final residence temperature for the cumulate pile.

According to the model trends for $\delta^{18} \mathrm{O}_{\text {Olivine }}$, measured values for cumulus olivines are $0-0.2 \%$ heavier than equilibrium values. Variations in residence time and system temperature may provide a mechanism to generate the observed isotopic diversity. To test this, we solved the equation for diffusion in a sphere (Crank 1975), using diffusion coefficients from Ryerson et al. (1989) and oxidising conditions of NNO +2 (Pichavant and Macdonald 2007). The temperature difference required for a $0.2 \%$ change in olivine-melt isotopic fractionation is $\sim 150^{\circ} \mathrm{C}$, consistent with the range of isotopic temperatures recorded by olivine-plagioclase pairs. Given the average liquidus temperature from Pichavant and Macdonald (2007) of $1,200^{\circ} \mathrm{C}$, a final storage temperature of $\sim 1,050^{\circ} \mathrm{C}$ is required, which would be consistent with the calculated isotopic disequilibria, the temperatures recorded by olivine-spinel pairs and the upper end of hornblende-plagioclase temperatures. At this temperature, olivines of $0.94 \mathrm{~mm}$ diameter (average for the samples analysed) would take $\sim 10^{5}$ years to fully re-equilibrate. However, to preserve a $0.1-0.2 \%$ disequilibrium between olivine and melt would require timescales less than $\sim 50,000$ years, a value broadly consistent with magma residence times calculated by Heath et al. (1998). For the slightly lower temperatures recorded by some hornblende-plagioclase pairs, the full re-equilibration time would be longer by up to a factor of 10 .

We propose that variations in residence time and to a lesser extent, temperature, provide the most plausible explanation for the diversity of olivine isotopic values and plagioclase-olivine isotopic temperatures in the cumulate samples studied. There is no a priori need to invoke mantle-derived parental magmas with a diversity of oxygen isotope signatures.
Origin of high An, low Fo cumulate compositions

The compositional contrast between cumulus plagioclase and olivine is a characteristic feature of plutonic rocks from various arc settings around the world. It is commonly assumed that high water contents $\left(>2 \mathrm{wt} \% \mathrm{H}_{2} \mathrm{O}\right)$ in melts of basaltic to basaltic-andesite composition are capable of generating high anorthite ('primitive') plagioclase and coexisting low-Fo olivine, achieved by suppression of the albite component in plagioclase solid solution (Arculus and Wills 1980; Sisson and Grove 1993). However, experimental studies performed on appropriate melt compositions have failed to generate coexisting mineral compositions quite as extreme as those observed in cumulate samples (Sisson and Grove 1993; Pichavant and Macdonald 2007).

Using the melt-plagioclase thermobarometric calibrations of Putirka (2005), we developed a model to investigate under which $\mathrm{P}-\mathrm{H}_{2} \mathrm{O}-\mathrm{X}$ conditions natural melts from St. Vincent would generate olivine and plagioclase of cumulus composition. The hornblende-hosted melt inclusion from sample VS3-2 (plagioclase hornblendite) was taken as a representative melt composition for the cumulates. Based on the late appearance of hornblende in the crystallisation sequence, well-equilibrated cumulate texture and lack of degassing features in hornblende, it is likely that this melt inclusion accurately reflects the chemical and volatile contents of evolved end member cumulate-derived melts.

The two unknowns remaining in our formulation are melt water content and pressure. Water content of this melt inclusion was estimated using the $\mathrm{Al}_{2} \mathrm{O}_{3}$-in-melt hygrometer from Pichavant and Macdonald (2007), calibrated for hydrous basaltic liquids from St. Vincent. This produced a value of $4.6 \pm 0.5 \mathrm{wt} \%$ at $1,000^{\circ} \mathrm{C}$, the average temperature recorded from hornblende-plagioclase chemical equilibria (Holland and Blundy, 1994). It is important to note that this calibration is only applicable for liquids at or close to the point of plagioclase saturation. The host cumulate contains plagioclase; however, since this melt inclusion records such high $\mathrm{Al}_{2} \mathrm{O}_{3}$ and $\mathrm{CaO}$ (20.6 and 8.1 $\mathrm{wt} \%$, respectively), it is unlikely that plagioclase crystallisation was quantitatively sufficient to significantly alter the melt composition and so the water content remains a reasonable minimum estimate. Moreover, a value of 4.6 $\mathrm{wt} \% \mathrm{H}_{2} \mathrm{O}$ is in keeping with the range of primary magmatic $\mathrm{H}_{2} \mathrm{O}$ contents determined by Bouvier et al. (2008). To constrain crystallisation pressure, we used the plagioclase + liquid thermobarometer and plagioclase saturation surface models of Putirka (2005) to calculate the locus of $\mathrm{P}-\mathrm{H}_{2} \mathrm{O}$ values under which the analysed plagioclase composition from VS3-2 $\left(A n_{94.3}\right)$ would be in equilibrium with the hornblende-hosted melt inclusion (Fig. 12). For a melt 


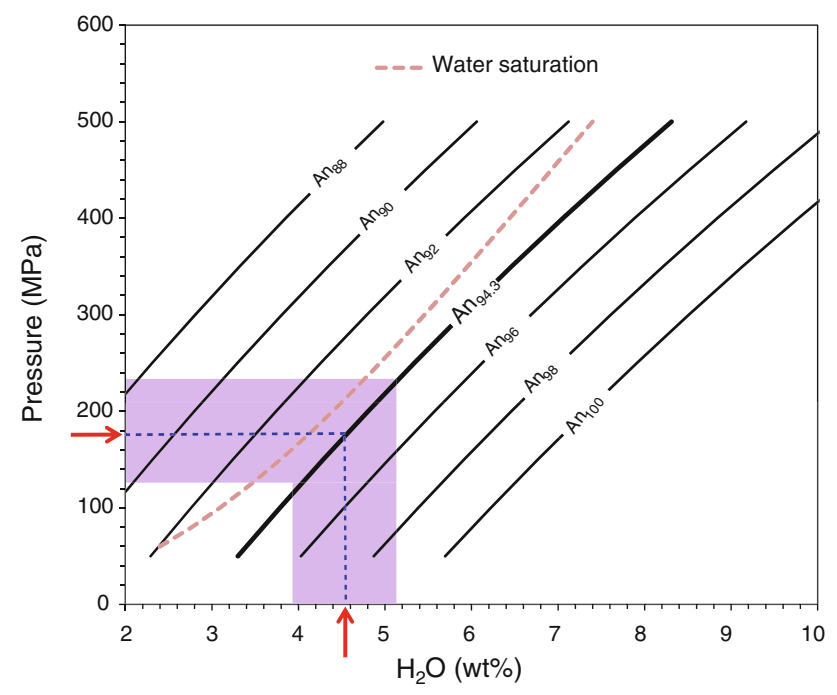

Fig. 12 Relationship between magmatic water content and pressure in generating $A n$-rich plagioclase for hornblende-hosted melt inclusion from sample VS3-2. Solid lines show equilibrium An content of liquidus plagioclase constructed using plagioclase-melt thermobarometers from Putirka (2005). Plagioclase liquidus temperature decreases with increasing $\mathrm{H}_{2} \mathrm{O}$ content. The broken red line shows water saturation for a basaltic melt $\left(49 \mathrm{wt} \% \mathrm{SiO}_{2}\right)$, calculated using VolatileCalc (Newman and Lowenstern 2002). A magmatic $\mathrm{H}_{2} \mathrm{O}$ content of $4.6 \pm 0.5 \mathrm{wt} \%$ was estimated using the $\mathrm{Al}_{2} \mathrm{O}_{3}$-in melt hygrometer from Pichavant and Macdonald (2007). A melt with this water content would saturate with $A n_{94.3}$ at $173 \pm 50 \mathrm{MPa}$, consistent with the composition observed in cumulates. Shaded area reflects error in methods of estimating $\mathrm{H}_{2} \mathrm{O}$ and $\mathrm{P}$

with $4.6 \mathrm{wt} \%, \mathrm{H}_{2} \mathrm{O}$ crystallisation of $A n_{94.3}$ plagioclase would require a pressure of $173 \mathrm{MPa}$. This is close to water-saturated conditions for a basalt at $1,000^{\circ} \mathrm{C}$, suggesting that a water- and plagioclase-undersaturated, $\mathrm{Ca}$ and Al-rich melt with $4.6 \mathrm{wt} \%$ generated at depth within the crust would attain saturation in water and calcic plagioclase upon ascent to $\sim 170 \mathrm{MPa}$.

We used these estimates of pressure and melt $\mathrm{H}_{2} \mathrm{O}$ content to calculate the plagioclase compositions in equilibrium with St. Vincent lava compositions from Robertson (2003) and Heath et al. (1998). Olivine compositions were also calculated, assuming a $\mathrm{Kd}_{\mathrm{Fe}-\mathrm{Mg}}$ of 0.3 , as determined experimentally by Pichavant and Macdonald (2007) for St. Vincent magmas. The results are plotted in Fig. 13. Also plotted are the values for the two sets of olivine-hosted melt inclusions from sample VS36 (melt inclusions PECcorrected to be in equilibrium with $\mathrm{Fo}_{75.7}$, the value of the host olivines) and the hornblende-hosted melt inclusion from VS3-2.

The results span a wide range in An-Fo space; however, a subgroup of St. Vincent lavas reported by Robertson (2003), with higher $\mathrm{FeO} / \mathrm{MgO}$ and high $\mathrm{Al}_{2} \mathrm{O}_{3}$ and $\mathrm{CaO}$ contents ( $\leq 22 \mathrm{wt} \%$ and $11 \mathrm{wt} \%$, respectively), accurately reproduce both the compositions of cumulus olivine and plagioclase and their associated positive correlation.

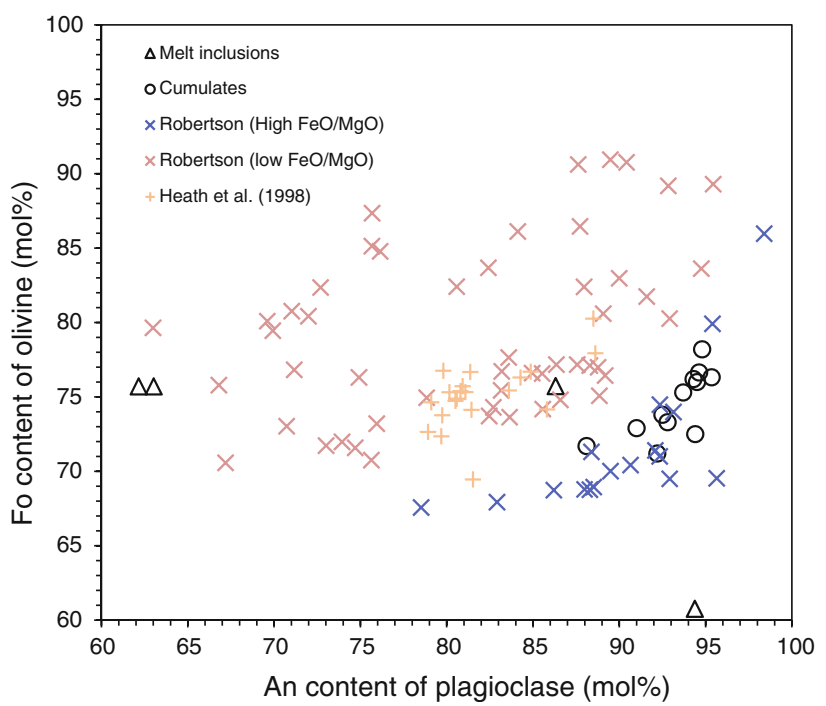

Fig. 13 Calculated An content of plagioclase and Fo content of olivine for lavas from Heath et al. (1998) and Robertson (2003) and melt inclusions from this study with $4.6 \mathrm{wt} \% \mathrm{H}_{2} \mathrm{O}$ and at $173 \mathrm{MPa}$. Also shown is the range of $F o$ and $A n$ in cumulates. Note that a subset of the lavas reproduce the olivine and plagioclase compositions of the cumulates under these conditions

Although the high-alumina basalts and basaltic andesites from St. Vincent are typically plagioclase-phyric, and therefore may not be truly representative of liquids, the existence of high-alumina liquids at St. Vincent is supported by the melt inclusion from VS3-2 $\left(20 \mathrm{wt} \% \mathrm{Al}_{2} \mathrm{O}_{3}\right)$.

The melt inclusions themselves do not match the cumulates quite as well in terms of calculated $F o$ and $A n$ compositions (Fig. 13). The hornblende-hosted melt inclusion from VS3-2 is in equilibrium with an even more extreme composition $\left(\mathrm{An}_{94.4}\right.$ and $\left.\mathrm{Fo}_{60.8}\right)$ than the cumulates, although the mismatch is likely within error of the observed cumulate compositions, given the methodology used and lack of correction for $\mathrm{Fe}^{3+}$. The olivine-hosted melt inclusions from VS36 both plot at lower An contents than the host cumulate. The more primitive of the two melt inclusion compositions may record differentiation prior to plagioclase saturation, a likely possibility given the earlier appearance of olivine in the crystallisation sequence, lower $\mathrm{Al}_{2} \mathrm{O}_{3}$ and $\mathrm{Mg \#}$. The more evolved melt inclusion (also hosted by olivine) is in equilibrium with substantially less anorthitic plagioclase than the host cumulate $\left(A n_{63}\right)$, although it does approach the low $A n$ content of interstitial microlite plagioclase from that sample $\left(A n_{58.8}\right)$ and is consistent with more evolved plagioclase rims in St. Vincent lavas (Fig. 8a).

To summarise, liquids rich in $\mathrm{Al}_{2} \mathrm{O}_{3}$ and $\mathrm{CaO}$, but low in $\mathrm{MgO}$, are an inevitable consequence of crystallising olivine-rich residues from hydrous melts at relatively high pressure, where plagioclase is not a stable liquidus phase. Our calculations suggest that such liquids will precipitate 
calcic plagioclase and relatively evolved olivine when they ascend from their deep source regions and attain $\mathrm{H}_{2} \mathrm{O}$ saturation at shallow depth. In the case of a hornblendehosted melt inclusion from sample VS3-2 (at $1,000^{\circ} \mathrm{C}$ ) with 4.6 wt $\% \mathrm{H}_{2} \mathrm{O}$, equilibrium with $A n_{94.3}$ would occur at $173 \mathrm{MPa}$, respectively. A similar range of depths and magmatic $\mathrm{H}_{2} \mathrm{O}$ contents can be calculated for high-alumina lavas from St. Vincent. These pressure- $\mathrm{H}_{2} \mathrm{O}$ conditions are outside the range studied experimentally by Pichavant et al. (2002) and Pichavant and Macdonald (2007).

\section{Cumulate petrogenesis at St. Vincent}

The cumulate samples in this study likely represent a relatively late, shallow stage of magma differentiation on St. Vincent. The unique coexisting olivine and plagioclase compositions require first the production of a hydrous, high-alumina basaltic or basaltic andesite liquid with associated low Mg\#. This can be produced by deep crustal differentiation of hydrous, mantle-derived basalt in a crustal hot zone, as described by Annen and Sparks (2002), under conditions that suppress plagioclase saturation. Crystallisation of olivine $+\mathrm{Cr}$ spinel \pm clinopyroxene would rapidly lower the $\mathrm{Mg \#}$ of the melt whilst driving up the $\mathrm{Al}_{2} \mathrm{O}_{3}$ and $\mathrm{CaO}$ contents. Segregation of such melts from their source region and ascent into the shallow crust would lead to both $\mathrm{H}_{2} \mathrm{O}$ saturation and precipitation of calcic plagioclase. We calculate that the conditions required to generate the observed combination of relatively evolved olivine $\left(\mathrm{Fo}_{70-80}\right)$ but calcic plagioclase $\left(A n_{86-96}\right)$ are approximately $170 \mathrm{MPa}$ and $4.6 \mathrm{wt} \% \mathrm{H}_{2} \mathrm{O}$. Ascent must have occurred relatively rapidly, or under conditions of significant magmatic superheat, as envisaged by Annen et al. (2006), to prevent crystallisation of initially lower anorthite plagioclase en route. We suggest a deep crustal magmatic 'launch pad' for high-alumina, low Mg\# melts, controlled by their density and viscosity. Substantial olivine crystallisation in the deep crustal hot zone would rapidly reduce the density of melt, allowing it to buoyantly rise through the crust until stalling at or near the watersaturated liquidus. This hydrous, lower-pressure melt would then crystallise the observed characteristic cumulate assemblage of plagioclase with $>85 \mathrm{~mol} \% \mathrm{An}$ and olivine with $<80 \mathrm{~mol} \%$ Fo. This second stage of differentiation involved little or no assimilation of isotopically distinct crustal material, as evidenced by normal (mantle-like) oxygen and hydrogen isotope values for crystals and calculated melt. Once deposited, the crystalline residue would remain stored within the crust, cooling sufficiently to saturate with hornblende \pm clinopyroxene. Storage times must have been less than $10^{5}$ years, in order to preserve slight oxygen isotope disequilibrium between coexisting plagioclase and olivine.
The observed cumulate assemblage requires a combination of melt compositions, water contents and pressures that have not been evaluated experimentally, hence the failure of extant experiments to reproduce the cumulates. Our proposal is directly amenable to testing experimentally, given appropriate starting materials and conditions.

\section{Conclusions}

1. Cumulate xenoliths on St. Vincent do not display correlation between the significant variation in modal mineralogy and relatively narrow range of mineral compositions. In addition, the relative appearance of plagioclase and clinopyroxene in the crystallisation sequence is correlated with the presence or absence of hornblende. This demonstrates that the samples in this study originated from distinct batches of chemically and isotopically similar mantle-derived melt with variable $\mathrm{H}_{2} \mathrm{O}$, which strongly influenced the relative appearance of plagioclase and hornblende.

2. The oxygen isotope composition of all cumulus phases and the hydrogen isotope composition of hornblende are consistent with typical values for closed system arc magmas and do not support assimilation of isotopically distinct crust.

3. Fractional crystallisation modelling of primitive St. Vincent melts shows that whilst variations in $\mathrm{P}-\mathrm{T}-$ $\mathrm{H}_{2} \mathrm{O}$ of different mantle-derived magma batches can influence the oxygen isotope composition of melt, the oxygen isotope composition of olivines precipitating from the melt is not significantly affected. Therefore, the observed range of $\delta^{18} \mathrm{O}_{\text {Olivine values and the lack of }}$ correlation with $\mathrm{Mg \#}$ cannot be explained solely by fractional crystallisation of a primary melt with a single $\delta^{18} \mathrm{O}$ signature.

4. Comparison of cumulus $\delta^{18} \mathrm{O}_{\text {Olivine values with mod- }}$ elled (i.e. equilibrium) values reveals that the majority of sampled olivines are isotopically heavier by up to $0.2 \%$. This may be achieved by incomplete oxygen isotope diffusive re-equilibration between coexisting phases during prolonged storage prior to remobilisation and eruption. Olivine crystallising at a higher temperature than the final crustal storage temperature would retain its original magmatic $\delta^{18} \mathrm{O}$ value due to the slower rate of oxygen diffusion in olivine compared to coexisting plagioclase. Complete isotopic reequilibration would be achieved within $10^{5}$ years, with much smaller timescales allowing preservation of isotopic disequilibrium.

5. Contrasting high anorthite $\left(A n_{>85}\right)$ plagioclase and low $\mathrm{Mg \#}\left(F o_{<80}\right)$, olivine in cumulate samples is unlike mineral compositions found in the lavas or produced in 
experiments. Modelling of plagioclase saturation in high $\mathrm{Al}_{2} \mathrm{O}_{3}$ and $\mathrm{CaO}$ hydrous melts, similar to cumulate-hosted melt inclusions and erupted lavas, indicates a two-stage petrogenesis of such mineral assemblages. High-pressure (deep crust) fractionation of olivine $+\mathrm{Cr}$ spinel \pm clinopyroxene from a hydrous, primitive basalt produces $\mathrm{Al}$ - and $\mathrm{Ca}$-rich hydrous melt, with low Mg\#. Upon segregation and rapid ascent to lower pressure (shallow crust), $\mathrm{H}_{2} \mathrm{O}$ saturation occurs and the melts coprecipitate $A n$-rich plagioclase and $F o$-poor olivine. Thus, we propose that the St. Vincent cumulates were deposited in a relatively shallow ( $\sim 5 \mathrm{~km}$ deep) magma storage region above a deep crustal hot zone, of the type envisaged by Annen et al. (2006).

Acknowledgments JDB acknowledges research funding from the Leverhulme Trust (F/00182/AY) and European Research Council (247162-CRITMAG). We would like to thank S. Kearns for help with Bristol electron microprobe, J. Palandri for assistance with stable isotope analyses and J. Fawcett-Thorne for thin section preparation. PMET would like to thank E. Melekhova and R. Arculus for constructive discussions. Reviews by E. Martin and M. Portnyagin were gratefully received.

\section{References}

Anderson DJ, Lindsley DH, Davdison PM (1993) QUILF: a pascal program to assess equilibria among $\mathrm{Fe}-\mathrm{Mg}-\mathrm{Mn}-\mathrm{Ti}$ oxides, pyroxenes, olivine, and quartz. Comput Geosci 19:1333-1350

Annen C, Sparks RSJ (2002) Effects of repetitive emplacement of basaltic intrusions on thermal evolution and melt generation in the crust. Earth Planet Sci Lett 203:937-955

Annen C, Blundy JD, Sparks RSJ (2006) The genesis of intermediate and silicic magmas in deep crustal hot zones. J Petrol 47(3):505-539

Arculus RJ (1994) Aspects of magma genesis in arcs. Lithos 33:189-208

Arculus RJ, Wills KJA (1980) The petrology of plutonic blocks and inclusions from the Lesser Antilles Island Arc. J Petrol 21(4):743-799

Ballhaus C, Berry RF, Green DH (1991) High pressure experimental calibration of the olivine-orthpyroxene-spinel oxygen geobarometer: implications for the oxidation state of the upper mantle. Contrib Mineral Petrol 107:27-40

Bindeman I (2008) Oxygen isotopes in Mantle and Crustal Magmas revealed by single crystal anlaysis. Rev Mineral Geochem 69:445-478

Bindeman IN, Ponomareva VV, Bailey JC, Valley JW (2004) Volcanic arc of Kamchatka: a province with high- $\delta^{18} \mathrm{O}$ magma sources and large-scale ${ }^{18} \mathrm{O} /{ }^{16} \mathrm{O}$ depletion of the upper crust. Geochim Cosmochim Acta 68(4):841-865

Bolhar R, Weaver SD, Whitehouse MJ, Palin JM, Woodhead JD, Cole JW (2008) Sources and evolution of arc magmas inferred from coupled $\mathrm{O}$ and $\mathrm{Hf}$ isotope systematic of plutonic zircons from the Cretaceous Separation Point Suite (New Zealand). Earth Planet Sci Lett 268:312-324

Bouvier A-S, Métrich N, Deloule E (2008) Slab-derived fluids in the Magma sources of St. Vincent (Lesser Antilles Arc): volatile and light element imprints. J Petrol 49(8):1427-1448
Bouvier A-S, Deloule E, Métrich N (2010) fluid inputs to Magma sources of St. Vincent and Grenada (Lesser Antilles): new insights from trace elements in Olivine-hosted Melt inclusions. J Petrol 51(8):1597-1615

Chiba H, Chacko T, Clayton RN, Goldsmith JR (1989) Oxygen isotope fractionations involving diopside, forsterite, magnetite, and calcite: application to geothermometry. Geochim Cosmochim Acta 53:2985-2995

Clowe CA, Popp RK, Fritz SJ (1988) Experimental investigation of the effect of oxygen fugacity on ferric-ferrous ratios and unit-cell parameters of four natural clinoamphiboles. Am Mineral 73:487-499

Cooper KM, Eiler JM, Asimow PD, Langmuir CH (2004) Oxygen isotope evidence for the origin of enriched mantle beneath the mid-Atlantic ridge. Earth Planet Sci Lett 220:297-316

Crank J (1975) The mathematics of diffusion, 2nd edn. Oxford University Press, Oxford

Danyushevsky LV, Plechov P (2011) Petrolog3: integrated software for modelling crystallisation processes. Geochem Geophys Geosyst, doi: 10.1029/2011GC003516

Davidson JP, Harmon RS (1989) Oxygen isotope constraints on the petrogenesis of volcanic arc magmas from Martinique, Lesser Antilles. Earth Planet Sci Lett 95:255-270

Davidson J, Turner S, Handley H, Macpherson C, Dosseto A (2007) Amphibole "sponge" in arc crust? Geology 35(9):787-790

DeBari SM, Coleman RG (1989) Examination of the deep levels of an island arc-evidence from the Tonsina ultramafic-mafic assemblage, Tonsina, Alaska. J Geophys Res 94:4373-4391

Deer WA, Howie RA, Zussman J (1996) An introduction to the rockforming minerals. Prentice Hall, Englewood Cliffs

Droop GTR (1987) A general equation for estimating $\mathrm{Fe}^{3+}$ concentrations in ferromagnesian silicates and oxides from microprobe analyses, using stoichiometric analyses, using stoichiometric criteria. Mineral Mag 51:431-435

Dungan MA, Davidson J (2004) Partial assimilative recycling of the mafic plutonic roots of arc volcanoes: an example from the Chilean Andes. Geology 32:773-776

Eggins SM (1993) Origin and differentiation of picritic arc magmas, Ambae (Aoba), Vanuatu. Contrib Mineral Petrol 114:79-100

Eiler JM (2001) Oxygen isotope variations in basaltic lavas and upper mantle rocks. Rev Min Geochem 43:319-364

Eiler J, Crawford A, Elliott T, Farley KA, Valley JW, Stolper EM (2000) Oxygen isotope geochemistry of Oceanic-Arc Lavas. J Petrol 41(2):229-256

Elliott T, Plank T, Zindler A, White W, Bourdon B (1997) Element transport from slab to volcanic front at the Mariana arc. J Geophys Res (Solid Earth) 102(B7):14991-15019

Feeley TC, Sharp ZD $(1995){ }^{18} \mathrm{O} /{ }^{16} \mathrm{O}$ isotope geochemistry of silicic lava flows erupted from Volcán Ollagüe, Andean Central Volcanic Zone. Earth Planet Sci Lett 133:239-254

Feig ST, Koepke J, Snow JE (2010) Effect of oxygen fugacity and water on phase equilibria of a hydrous tholeiitic basalt. Contrib Mineral Petrol, doi:10.1007/s00410-010-0493-3

Garcia MO, Ito E, Eiler JM (2008) Oxygen isotope evidence for chemical interaction of Kilauea Historical Magmas with Basement Rocks. J Petrol 49:757-769

Greene AR, DeBari SM, Kelemen PB, Blusztajn J, Clift PD (2006) A detailed geochemical study of island arc crust: the Talkeetna Arc section, south-central Alaska. J Petrol 47:1051-1093

Grove TL, Elkins-Tanton LT, Parman SW, Chatterjee N, Müntener O, Gaetani GA (2003) Fractional crystallisation and mantle-melting controls on calc-alkaline differentiation trends. Contrib Mineral Petrol 145:515-533

Grove TL, Till CB, Lev E, Chatterjee N, Médard E (2009) Kinematic variables and water transport control the formation and location of arc volcanoes. Nature 459:694-697 
Harford CL, Sparks RSJ (2001) Recent remobilisation of shallowlevel intrusions on Montserrat revealed by hydrogen isotope composition of amphiboles. Earth Planet Sci Lett 185:285-297

Harmon RS, Hoefs J (1995) Oxygen isotope heterogeneity of the mantle deduced from global ${ }^{18} \mathrm{O}$ systematics of basalts from different geotectonic settings. Contrib Mineral Petrol 120:95-114

Harris C, Stuart Smith H, Le Roex AP (2000) Oxygen isotope composition of phenocrysts from Tristan da Cunha and Gough Island lavas: variation with fractional crystallisation and evidence for assimilation. Contrib Mineral Petrol 138:164-175

Heath E, Macdonald R, Belkin H, Hawkesworth C, Sigurdsson H (1998) Magmagenesis at Soufriere Volcano, St Vincent, Lesser Antilles Arc. J Petrol 39(10):1721-1764

Holland T, Blundy J (1994) Nonidea interactions in calcic amphiboles and their bearing on amphibole-plagioclase thermometry. Contrib Mineral Petrol 116:433-447

James DE (1981) The combined use of oxygen and radiogenic isotopes as indicators of crustal contamination. Ann Rev Earth Planet Sci 9:311-344

Kohn MJ, Valley JW (1998) Effects of cation substitutions in garnet and pyroxene on equilibrium oxygen isotope fractionations. J Met Geol 16:625-639

Kyser TK, O'Neil JR (1984) Hydrogen isotope systematic of submarine basalts. Geochim Cosmochim Acta 48:2123-2133

Larocque J, Canil D (2010) The role of amphibole in the evolution of arc magmas and crust: the case from Jurassic Bonanza arc section, Vancouver Island, Canada. Contrib Mineral Petrol 159:475-492

Lewis JF (1973) Mineralogy of the ejected plutonic blocks of the Soufriere Volcano St. Vincent: olivine, pyroxene, amphibole and magnetite paragenesis. Contrib Mineral Petrol 38:197-220

Macdonald R, Hawkesworth CJ, Heath E (2000) The Lesser Antilles volcanic chain: a study in arc magmatism. Earth Sci Rev 49:1-76

Macpherson CG, Mattey DP (1998) Oxygen isotope variations in Lau Basin lavas. Chem Geol 144:177-194

Mattey D, Lowry D, Macpherson C (1994) Oxygen isotope composition of mantle peridotite. Earth Planet Sci Lett 128:231-241

McDade P, Blundy JD, Wood BJ (2003) Trace element partitioning between mantle wedge peridotite and hydrous $\mathrm{MgO}$-rich melt. Am Mineral 88:1825-1831

Newman S, Lowenstern JB (2002) VolatileCalc: a silicate melt- $\mathrm{H}_{2} \mathrm{O}$ $\mathrm{CO}_{2}$ solution model written in Visual Basic for excel. Comput Geocsci 28:597-604

Pichavant M, Macdonald R (2007) Crystallization of primitive basaltic magmas at crustal pressures and genesis of the calcalkaline igneous suite: experimental evidence from St Vincent, Lesser Antilles arc. Contrib Mineral Petrol 154:535-558

Pichavant M, Mysen BO, Macdonald R (2002) Source and $\mathrm{H}_{2} \mathrm{O}$ content of high-MgO magmas in island arc settings: An experimental study of a primitive calc-alkaline basalt from St. Vincent, Lesser Antilles arc. Geochim Cosmochim Acta 66(12):2193-2209

Putirka KD (2005) Igneous thermometers and barometers based on plagioclase + liquid equilibria: tests of some existing models and new calibrations. Am Mineral 90:336-346
Robertson REA (2003) The volcanic geology of the pre-Soufrière Rocks of the St. Vincent, West Indies. PhD Thesis, University of the West Indies, Trinidad

Romick JD, Kay SM, Kay RW (1992) The influence of amphibole fractionation on the evolution of calc-alkaline andesite and dacite tephra from the Central Aleutians, Alaska. Contrib Mineral Petrol 112:101-118

Ryerson FJ, Durham WB, Cherniak DJ, Lanford WA (1989) Oxygen diffusion in olivine: effect of oxygen fugacity and implications for creep. J Geophy Res (Solid Earth) 94:4105-4118

Sharp ZD, Atudorei V, Durakiewicz T (2001) A rapid method for determination of hydrogen and oxygen isotope ratios from water and hydrous minerals. Chem Geol 178:197-210

Shaw AM, Hauri EH, Fischer TP, Hilton DR, Kelley KA (2008) Hydrogen isotopes in Mariana arc melt inclusions: Implications for subduction dehydration and the deep-Earth water cycle. Earth Planet Sci Lett 275:138-145

Sisson TW, Grove TL (1993) Experimental investigations of the role of $\mathrm{H}_{2} \mathrm{O}$ in calc-alkaline differentiation and subduction zone magmatism. Contrib Mineral Petrol 113:143-166

Smith TE, Thirlwall MF, Macpherson C (1996) Trace element and isotope geochemistry of the Volcanic Rocks of Bequia, Grenadine Islands, Lesser Antilles Arc: a study of subduction enrichment and itra-crustal Contamination. J Petrol 37(1):117-143

Streckeisen A (1976) To each plutonic rock its proper name. Earth Sci Rev 12:1-33

Thirlwall MF, Graham AM, Arculus RJ, Harmon RS, Macpherson CG (1996) Resolution of the effects of crustal assimilation, sediment subduction, and fluid transport in island arc magmas: $\mathrm{Pb}-\mathrm{Sr}-\mathrm{Nd}-\mathrm{O}$ isotope geochemistry of Grenada, Lesser Antilles. Geochim Cosmochim Acta 60(23):4785-4810

Valley JW, Lackey JS, Cavosie AJ, Clechenko CC, Spicuzza MJ, Basei MAS, Bindeman IN, Ferreira VP, Sial AN, King EM, Peck WH, Sinha AK, Wei CS (2005) 4.4 billion years of crustal maturation: oxygen isotope ratios of magmatic zircon. Contrib Mineral Petrol 150:561-580

Van Soest MC, Hilton DR, Macpherson CG, Mattey DP (2002) Resolving sediment subduction and crustal contamination in the Lesser Antilles Island Arc: a combined $\mathrm{He}-\mathrm{O}-\mathrm{Sr}$ isotope approach. J Petrol 43(1):143-170

Villiger S, Ulmer P, Müntener O, Thompson AB (2004) the liquid line of descent of anhydrous, mantle-derived, tholeiitic liquids by fractional and equilibrium crystallisation-an experimental study at $1.0 \mathrm{GPa}$. J Petrol 45(12):2369-2388

Widom E, Farquhar J (2003) Oxygen isotope signatures in olivines from São Miguel (Azores) basalts: implications for crustal and mantle processes. Chem Geol 193:237-255

Zellmer GF, Hawkesworth CJ, Sparks RSJ, Thomas LE, Harford CL, Brewer TS, Loughlin SC (2003) Geochemical evolution of the Soufrière Hills Volcano, Montserrat, Lesser Antilles Volcanic Arc. J Petrol 44(8):1349-1374

Zhao Z, Zheng Y (2003) Calculation of oxygen isotope fractionation in magmatic rocks. Chem Geol 193:59-80 